DIW BERLIN

Discussion

Papers
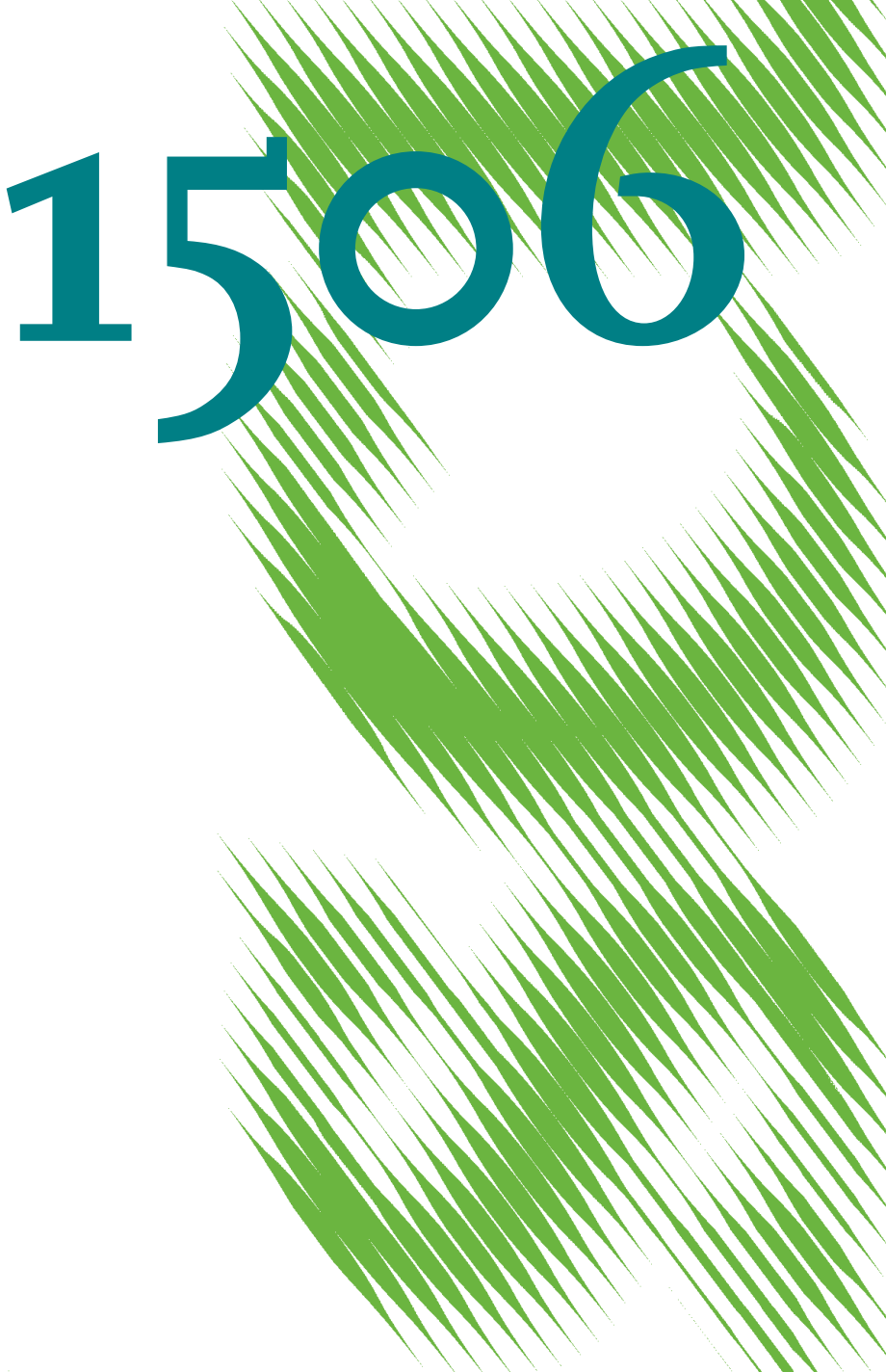

Non-economic Damages in Medical Malpractice Appeals

Does the Jurisdiction Make a Difference? 
Opinions expressed in this paper are those of the author(s) and do not necessarily reflect views of the institute.

IMPRESSUM

(C) DIW Berlin, 2015

DIW Berlin

German Institute for Economic Research

Mohrenstr. 58

10117 Berlin

Tel. +49 (30) $89789-0$

Fax +49 (30) $89789-200$

http://www.diw.de

ISSN electronic edition 1619-4535

Papers can be downloaded free of charge from the DIW Berlin website:

http://www.diw.de/discussionpapers

Discussion Papers of DIW Berlin are indexed in RePEc and SSRN:

http://ideas.repec.org/s/diw/diwwpp.html

http://www.ssrn.com/link/DIW-Berlin-German-Inst-Econ-Res.html 


\title{
Non-economic Damages in Medical Malpractice Appeals: Does the jurisdiction make a difference?
}

\author{
Sofia Amaral-Garcia \\ September 2015
}

\begin{abstract}
This article assesses predictors of payouts and non-economic damages in medical malpractice cases decided by the Spanish Supreme Court from 2006 until 2010. Medical malpractice cases can be judged in administrative or civil courts, and this distinction heavily relies on the type of hospital where the medical accident took place (in general terms, administrative courts judge cases involving public hospitals and civil courts judge cases involving private hospitals). I find that cases decided by the Administrative Section of the Supreme Court are not more likely to receive damages than cases decided by the Civil Section. The probability of receiving compensation is significantly higher among cases involving permanent major/grave injuries.

With respect to non-economic compensation amounts, there are no significant differences between Administrative and Civil cases. This result is confirmed by matching estimation and simulation exercises. There is evidence of vertical inequality according to the level of harm: cases involving permanent grave injuries are those receiving the highest non-economic damages, followed by permanent major, death, permanent minor and temporary/emotional cases. Differences in compensation awards between Administrative and Civil courts has been one argument widely used against the current separation of jurisdictions in many civil law tradition countries. The results found in this paper do not support this claim.
\end{abstract}

Keywords: medical malpractice, non-economic damages, scheduled damages, Supreme Court, Spain, administrative and civil jurisdictions, litigation

JEL classification: K13, K32, K41

DIW Berlin, samaralgarcia@diw.de. I am grateful to Ted Eisenberg, Michael Faure, Nuno Garoupa, Fernando Goméz-Pomar, Gerard Hertig, David Hyman, Jonathan Klick, Mattia Nardotto, Sonia Ramos, Louis Visscher, Rainer Winkelmann, and European Conference on Health Economics (Zurich), AEDE 2012 (Valencia), ETH Zurich and University of Zurich seminar participants for very useful comments and suggestions on a preliminary version of this paper (Medical Accidents: Predicting Compensation). Financial support is acknowledged to FCT, Portuguese Ministry of Higher Education and Science, grant SFRH/BD/37917/2007. The usual disclaimers apply. 


\section{Introduction}

"To err is human'1 but "to sue is human'|2 too. When victims of medical malpractice (med mal) sue their doctors, courts will have to assess first whether the doctor was negligent and if that substandard treatment caused the injury suffered by the patient. Medical malpractice is naturally very complex to assess due to problems of causation: for each patient we can only observe the final outcome given the treatment received (i.e., whether the patient is cured or if harm materialized). Having a counterfactual for a specific patient is impossible as we cannot go back in time, provide a different treatment and assess what the final outcome would be.

When courts decide that the substandard treatment caused the injury, a quantification of damages will follow. The quantification of damage ${ }^{3}$ is crucial for medical malpractice cases: the compensatory goal of tort law requires making the injured patient 'whole' and should deter negligent medical care. The general rule is that patients should be fully compensated by the harm suffered, and courts tend to award economic and non-economic damages.$^{4}$ While economic damages can be considered easier to compute, non-economic damages are seen as more controversial and difficult to quantify 5 Indeed, this component of damages should quantify pain and suffering sustained by victims. Given the importance of accuracy and fairness of awards for non-economic damages, clearer signals of likely outcomes should, among other things, "inspire greater confidence in the fairness and predictability of the tort recovery system (thereby helping to maintain the efficient operation of the deterrent function of tort law)" (Bovbjerg et al., 1989). Two characteristics should be observed when looking at non-economic damages: vertical inequality and horizontal equity. In other words, patients suffering higher levels of injury should receive higher non-economic damages and patients suffering similar injuries should receive an equivalent indemnity award 6

The empirical literature in law and economics has frequently analised these two important elements together, i.e., by assessing which are the predictors of compensation in medical malpractice cases and how is compensation being set. What these studies have generally shown

\footnotetext{
${ }^{1}$ Part of the title of the report from the Institute of Medicine (1999), which concludes that the number of yearly deaths due to preventable medical adverse events in the United States is higher than the number of deaths due to AIDS, breast cancer or motor vehicle accidents.

${ }^{2}$ Part of the title of Zeiler et al. (forthcoming).

${ }^{3}$ For a survey of the literature on tort damages, see Visscher (2009) and Arlen (2000).

${ }^{4}$ Some jurisdictions, such as the US, also award punitive damages.

${ }^{5}$ See Avraham (2006) and discussion herein.

${ }^{6}$ In this paper we will not assess how damages should be calculated or what is the fair or optimal compensation amount that victims shall receive. See, for instance, Bovbjerg et al. (1989) and Avraham (2006). See also Ubel and Loewenstein (2008). For the use of QALY's, see Karapanou and Visscher (2010). For a calculation of the value of statistical life using verdicts on damages for pain and suffering from Austria and Germany, see Leiter et al. (2012). Forensic economics can provide useful contributions to this area.
} 
is that there is no evidence of any skyrocketing compensation awards in medical malpractice cases (Black et al. (2005), Vidmar et al. (2005), Fenn et al. (2000)); when plaintiffs go to court or appeal, the probability of compensation is generally lower but in the event of compensation being awarded, awards tend to be higher (Studdert and Mello (2007), Danzon (1985), Sloan and Hsieh (1990)); compensation amounts tend to increase with injury levels up to permanent grave injury (cases involving death usually receive lower payouts than these cases) (Sloan and Hsieh (1990), Vidmar et al. (2005)). When it comes to the claim that the quantification of damages is random, the results are not always clear. On the one hand, there seems to be evidence that courts might not offer an indication of how to compute damages (i.e., neither when judges themselves are called upon to compute damages, nor when juries are asked to do so). On the other hand, evidence does not seem to lend support to the argument that awards are set randomly.

There is limited empirical evidence on the attribution of medical malpractice damages in general, and non-economic damages in particular, by courts in civil law tradition countries.7 This paper aims to contribute to the literature by using a dataset of all medical malpractice cases decided by the Spanish Supreme Court from 2006 until 2010. It departures from previous works by considering a specific feature of the Spanish legal system (which is also commonly found in other civil law tradition countries): a distinction between civil and administrative jurisdictions. ${ }^{8}$ Although there is no specific law to regulate physician-patient relationship in Spain, the type of healthcare provider that delivered the medical care is crucial for the legal process - i.e., if it is a public or private healthcare provider ${ }^{9}$ Therefore, whenever a medical accident takes place in a public hospital patients should file their claims in administrative courts, ${ }^{10}$ and whenever a medical accident takes place in a private hospital, patients should file their claims in civil courts ${ }^{11}$ Medical malpractice cases can be easily compared even if they have been decided in different jurisdictions. In practice, they follow the same rules concerning liability, causation,

\footnotetext{
${ }^{7}$ I am aware of an article by Chang et al. (2013) that assesses pain and suffering damages for personal injury cases (medical malpractice and car accidents) in Taiwan. Flatscher-Thöni et al. (2013) assess compensation for pain-andsuffering in Austrian courts and differences in the valuation method (per-diem or lump-sum scheme). Grembi and Garoupa (2013) assess Supreme Court decisions of medical malpractice in Italy, but the amount of compensation is not generally available for these cases.

${ }^{8}$ Spain is included in the civil law tradition by Mahoney (2001) and the legal origins literature. Moreover, although the issue of specialized administrative lawmaking received some attention in the US, the institutional arrangements are remarkably different.

${ }^{9}$ For more on the Spanish legal system in medical malpractice cases, see Ferrara et al. (2013), Koch (2011), Arroyo and Yágüez (2013), Martín-Casals et al. (2003), Amaral-Garcia and Garoupa (forthcoming 2015).

${ }^{10}$ For more on administrative courts see Amaral-Garcia (2015b).

${ }^{11}$ This distinction has been made clear after legislative reforms in 1998 and 1999 (Law 29/1998 of July 13 and Law 4/1999 of January 13).
} 
burden of proof, quantification of damages, grounds for reversal and court fees, to name a few ${ }^{12}$

Supreme Court decisions are relevant for many reasons, namely because they make new law, clarify the law, produce precedents, harmonize conflicting lower court decisions, benefit many parties in the future and allow for error correction (Shavell (2010)). In civil law countries, parties' right to appeal to the Supreme Court makes the number of appeals high and the majority of appeals might actually fail $[3$ These reasons make the study of Supreme Court decisions particularly interesting in civil law countries.

This article starts by testing if there are case characteristics that predict a positive payout in medical malpractice cases appealed to the Spanish Supreme Court. Subsequently, the legal separation between the administrative and civil jurisdiction ${ }^{14}$ is used to test the extent to which administrative courts might attribute different non-economic damages than civil courts. ${ }^{15}$ In a fair and equitable legal system, non-economic damages in medical malpractice cases attributed by civil courts should not present significant differences from non-economic damages attributed by administrative courts, ceteris paribus (i.e., after controlling for other variables, such as age and injury severity level). However, the "polycentric character" of the Spanish law of torts is responsible for several problems. One potential problem might be that, precisely because there is a distinction between civil and administrative jurisdictions, victims can be subject to different treatments in terms of quantification of damages, which is against the principle of equality granted by the Constitution (Gómez-Pomar and Sánchez Álvarez, 2006). In fact, opponents of the current separation of jurisdictions tend to argue that courts attribute different damages depending on whether the court adjudicating the case is civil or administrative. Nevertheless, extensive empirical evidence on this claim is virtually non-existent.

Why can medical malpractice damages be different in civil and administrative cases? The main difference between these cases is the identity of the defendant: the State (public hospitals) in administrative cases; and private parties (private hospitals) in civil cases 16 Courts might consider that, when the State is guilty, the compensation attributed to the plaintiff should be higher, as a way of punishing for the poor health care quality that has been provided with the taxpayers' money. However, courts might also take into account two things when setting

\footnotetext{
${ }^{12}$ See Amaral-Garcia and Garoupa (forthcoming 2015) for a detailed explanation and for reasons why these cases are comparable.

${ }^{13}$ See Shavell (2010). This claim is confirmed by medical malpractice cases appealed to the Spanish Supreme Court: the majority of cases reaching this court saw the previous decision being affirmed.

${ }^{14}$ See Amaral-Garcia and Garoupa (forthcoming 2015).

${ }^{15}$ I.e., after excluding economic damages (which in this setting are essentially loss of income and medical expenses). See Amaral-Garcia (2015) for more on non-economic damages in medical malpractice cases in Spain (in Spanish).

${ }^{16}$ For a general description of the Spanish medical liability system see Amaral-Garcia and Garoupa (forthcoming 2015) and Amaral-Garcia (2011).
} 
compensation: i) in case the plaintiff needs future medical treatments, these can be provided in public hospitals; ii) the damages attributed to the plaintiff will be paid by the taxpayers. These two arguments might take administrative courts to set lower compensation amounts. With respect to civil decisions, if civil courts believe that private hospitals have deep-pockets, they might award higher damages. Therefore, in case differences in non-economic damages exist, it is not clear in which type of decisions we should expect higher payouts. Moreover, given the setting that I am looking at (in which compensation for loss of income is excluded), a potential self-selection of patients into one type of hospital should not matter for the analysis. It would make a difference if, for instance, richer patients self-select into one type of hospital and these patients receive higher compensation for loss of income.

This paper proceeds as follows: Section 2 describes the medical malpractice liability system in Spain and the quantification of damages. Section 3 describes the dataset. The main findings are presented in Section 4, where a robustness checks, matching estimators, simulation and counterfactual outcomes are presented as well. Section 5 discusses the main results. Section 6 concludes.

\section{Medical Malpractice in Spain}

\subsection{Legal System and the Supreme Court}

There is no specific law that regulates the physician-patient relationship in Spain. Essentially the type of healthcare provider in which the medical injury took place determines the jurisdiction in which the case can be tried ${ }^{17}$ Therefore, a patient suffering harm in a public hospital must file a claim in the administrative jurisdiction while a patient harmed in a private hospital must go to the civil jurisdiction ${ }^{18}$ According to the law on the books one might eventually consider that two separate subsystems imposing different procedures to similar problems coexist within the same system, which is actually common in some civil law tradition countries with a public national health system (Amaral-Garcia (2011)). What case law shows is that, in practice, medical malpractice cases are similar in terms of legal procedure, which makes these cases comparable. Courts effectively apply a liability rule based on fault independently of the type of institution

\footnotetext{
${ }^{17}$ In this section, a brief description of the Spanish legal system is presented, as there are extensive descriptions elsewhere. See, among others, Martín-Casals et al. (2003), Koch (2011), Ferrara et al. (2013), Arroyo and Yágüez (2013), Amaral-Garcia (2011), Amaral-Garcia and Garoupa (forthcoming 2015) and Gómez-Pomar (2001).

${ }^{18} \mathrm{This}$ is also considerably different than what happens in the US. Spanish judges specialize in administrative or civil law, but they follow similar career paths. For more details, see Garoupa et al. (2012) and Dari-Mattiacci et al. (2010).
} 
where the accident took place. ${ }^{19}$

The burden of proof lies in both types of cases (administrative and civil) with the patient, who needs to prove fault and causation. A reversal of the burden of proof can be granted, but only in exceptional cases ${ }^{20}$ Cases with a disproportional harm in comparison with the risk of the medical intervention (daño desproporcionado) or cases in which the defendant is in a better position to provide evidence (such as that the patient signed the informed consent sheet), are the most common examples in which a reversal of the burden of proof can be granted.

All decisions made by Spanish courts on medical malpractice are made by judges, and there is no asymmetric information between administrative and civil judges ${ }^{21}$ Medical malpractice cases can be appealed to the Supreme Court, which is the court of last appeal in points of law only. Contrarily to the US Supreme court, the Spanish Supreme Court has no control over its docket and appeals are supposed to be of general importance and in reference to some relevant legal controversy ${ }^{22}$ Appealed cases from the administrative jurisdiction will be decided by the Administrative Section of the Supreme Court and those from the civil jurisdiction by the Civil Section.

\subsection{Quantification of damages}

As stated by Spanish law, the amount of compensation should be set by lower courts. The Supreme Court can modify the amount of compensation from lower courts, but only if there is evidence that the previous amount was unreasonable. Considering that "judges have professional and reputational interests in avoiding having their damage awards adjusted on appeal" (Eisenberg and Heise, 2011), we should only see small differences in the quantification of damages by lower courts and the Supreme Court, if any. Although this paper focuses on noneconomic damages, the Spanish liability system allows patients to recover damages for economic and non-economic losses. Awards for punitive damages are generally not possible in the vast majority of European countries. According to the organization of the Spanish National Health System and Social Security, cases of loss of income can be supported by social security. With

\footnotetext{
${ }^{19}$ This is important to notice because, according to administrative regulation, the public administration is strictly liable in tort. However, case law shows that there is no difference in terms of liability rules being applied to private and public hospitals: a general standard of liability based on fault is applied to both cases (Amaral-Garcia and Garoupa (forthcoming 2015)). There are also several decisions by the Supreme Court stating that strict liability will not be applied to administrative cases. See, for instance, ROJ STS 7800/2009 (18.12.2009).

${ }^{20}$ The reversal of the burden of proof in medical accidents is recent when compared with its application to other cases. See Gómez-Pomar (2001) and Luna Yerga (2005).

${ }^{21}$ In the US, asymmetric information between judges and juries might be play a role for setting damages. See Eisenberg and Heise (2011).

${ }^{24}$ See Garoupa et al. (2012) for the Spanish Supreme Court in general, and Amaral-Garcia and Garoupa (forthcoming 2015) for medical malpractice appeals to the Spanish Supreme Court.
} 
respect to medical expenses, social security will also have a role in these cases and the National Health System will provide medical treatment to injured patients.

Quantifying damages is difficult and implies several assumptions. In medical malpractice cases, judges are essentially asked to compute a value for an irreplaceable commodity: health (or even life). Judges are aware that the patient should be fully compensated (Ley 30/1992; Arts. 1106 and 1902, Civil Code), but no guidance is provided on how damages should be calculated ${ }^{23}$ To evaluate the health status of the patient, medical experts' reports can be used ${ }^{24}$ Moreover, both civil and administrative judges can easily have access to previous courts decisions and to how much compensation has been attributed in other cases.

Spanish judges are generally free to rely on scheduled damage tables that are used to quantify compensation for automobile accidents ${ }^{25}$ The use of scheduled damage tables should help courts quantifying harm and should allow for less discretion. However, more volatility in payouts can also arise if some judges use scheduled damages and others do not.

Compensation due to loss of a chance is being applied more frequently by Spanish courts ${ }^{26}$ In these cases, awards are necessarily lower with respect to full compensation. Asymmetric information models in litigation rely on the fact that the amount of damages is actually known by both parties but the doctor has more information with respect to the evidence of negligence. However, when courts award damages under the loss of a chance argument, the doctor is liable but the patient will receive damages corresponding to the loss of a chance in recovery. The court will estimate the probability of recovery in case the doctor would not have been negligent and uses it to assess the final amount of compensation. Although this probability tends to be grounded on medical evidence, there is more uncertainty involved with respect to the overall compensation amount, in the sense that first a calculation must be done for the harm, and subsequently for the probability of recovery.

To add to the lack of general rule to quantify damages, judges are even free to choose between a per-diem or lump-sum amount, although the Supreme Court is extremely reluctant to the attribution of per-diem awards ${ }^{27}$ This is confirmed in the sample: there are only 5 cases in which a per-diem payout was awarded, and in all these cases the amount of compensation had been set by lower courts.

As described above, there is no guidance in how courts should determine damages. There-

\footnotetext{
${ }^{23}$ This is true for several countries. For the US, see Bovbjerg et al. (1989). For Taiwan, see Chang et al. (2013).

${ }^{24}$ See Arroyo and Yágüez (2013).

${ }^{25}$ Royal Legislative Decree $8 / 2004$, October 29, on civil responsibility and insurance on motor vehicles (Responsabilidad Civil y Seguro en la Circulación de Vehículos a Motor).

${ }^{26}$ For a description of the introduction of the loss of a chance doctrine by the Spanish Supreme Court, see Luna Yerga (2005).

${ }^{27}$ See, for instance, ROJ STS 3429/208 (27.06.2008).
} 
fore, one might worry that awards may vary unpredictably ${ }^{28}$

\section{Dataset and Descriptive Statistics}

The dataset consists in all medical malpractice cases decided by the Spanish Supreme Court from 2006 until 2010 ${ }^{29}$ Several variables of interest have been collected, as described in Table 1. In order to categorize the severity of the injury, I followed the approach by Bovbjerg et al. (1989) in which the authors rely on a scale from the US National Association of Insurance Commissioners (see Table 6 in the Appendix). In my dataset, the number of cases involving the lowest levels of severity injury are almost nonexistent, especially if merely cases with a positive payout are considered: there are only 7 cases with a positive payout in which the level of harm was classified as emotional or temporary (whether insignificant, minor or major). For this reason, I created a new level of injury severity, Permanent Minor, which groups those levels of harm. Additionally, I had to group together what NAIC categorized as permanent minor and permanent significant levels of injury, in order to have a consistent measure. The same was done for cases with zero payout and with permanent major or permanent grave injury (it is possible to distinguish between these levels only for those cases in which a positive payout has been awarded). I am aware that this is a data limitation, but I consider that this does not bring important implications for the empirical analysis. On the one hand, the grouping of the lowest levels of harm is simply based on the non-existence of cases categorized as such; on the other hand, grouping together the levels mentioned before is the only way of having a consistent measure for the level of harm suffered by the patient 30 Moreover, the description of the harm is quite close for the groups that are now together.

\subsection{Data Description}

Table 2 provides information on the total number of cases decided by the Administrative and Civil Sections of the Spanish Supreme Court, according to the level of harm. From all cases arriving at the Supreme Court, 52\% involved the most severe levels of harm (permanent ma-

\footnotetext{
${ }^{28}$ Moreover, when doctors must choose among risky procedures, there are arguments that favor an attribution of damages lower than the harm suffered by the patient (Cooter and Porat 2006). Were courts to apply this reasoning, they would also need to make calculations for the procedure that the doctor did not choose. For a proposal of negligence-based proportional liability applicable to medical malpractice cases, see Stremitzer (2012).

${ }^{29}$ For a detailed explanation of this dataset and on how it was built, see Amaral-Garcia (2011).

${ }^{30}$ Essentially, this has to do with the information provided for cases to which compensation has not been awarded. It turns out that in some cases the information is not extensive enough so that one can affirm precisely whether the harm shall be considered as permanent minor or permanent significant, but there is no doubt that it should be one or the other. The same holds for permanent major and permanent grave cases.
} 
Table 1: Descriptive Statistics

\begin{tabular}{|c|c|c|c|c|c|c|}
\hline \multirow[b]{2}{*}{ Variable } & \multicolumn{2}{|c|}{ Administrative } & \multicolumn{2}{|c|}{ Civil } & \multicolumn{2}{|c|}{ All Sample } \\
\hline & Mean & SD & Mean & SD & Mean & SD \\
\hline Compensation awarded [D] & 0.47 & 0.50 & 0.49 & 0.50 & 0.47 & 0.50 \\
\hline Newborn [D] & 0.19 & 0.39 & 0.13 & 0.34 & 0.17 & 0.38 \\
\hline Child [D] & 0.08 & 0.28 & 0.06 & 0.24 & 0.08 & 0.27 \\
\hline Adult/Elderly [D] & 0.73 & 0.45 & 0.80 & 0.40 & 0.75 & 0.43 \\
\hline Adult $[\mathrm{D}](+)$ & 0.65 & 0.48 & 0.64 & 0.49 & 0.65 & 0.48 \\
\hline Elderly [D] (+) & 0.04 & 0.19 & 0.09 & 0.28 & 0.05 & 0.22 \\
\hline Words & 3938 & 1750 & 4560 & 3415 & 4130 & 2403 \\
\hline Duration LCSC (Months) & 46.9 & 14.4 & 81.7 & 14.0 & 57.6 & 21.5 \\
\hline Plaintiff Appeals [D] & 0.85 & 0.36 & 0.68 & 0.47 & 0.80 & 0.40 \\
\hline Defendant Appeals [D] & 0.18 & 0.39 & 0.38 & 0.49 & 0.24 & 0.43 \\
\hline Both Parties Appeal [D] & 0.03 & 0.18 & 0.06 & 0.24 & 0.04 & 0.20 \\
\hline Male [D] & 0.51 & 0.50 & 0.55 & 0.50 & 0.52 & 0.50 \\
\hline Harm Level ( 1 to 4 ) & 2.67 & 0.82 & 2.59 & 0.96 & 2.64 & 0.87 \\
\hline Temporary/Emotional Harm [D] & 0.05 & 0.22 & 0.11 & 0.31 & 0.07 & 0.25 \\
\hline Permanent Minor [D] & 0.40 & 0.49 & 0.43 & 0.50 & 0.41 & 0.49 \\
\hline Permanent Major/Grave [D] & 0.37 & 0.48 & 0.23 & 0.42 & 0.33 & 0.47 \\
\hline Death $[\mathrm{D}]$ & 0.17 & 0.38 & 0.23 & 0.42 & 0.19 & 0.39 \\
\hline Individual Defendant [D] & 0.03 & 0.18 & 0.88 & 0.33 & 0.29 & 0.46 \\
\hline Institutional Defendant [D] & 1 & 0 & 0.87 & 0.34 & 0.96 & 0.20 \\
\hline SC Reverses LCourt [D] & 0.21 & 0.41 & 0.14 & 0.35 & 0.19 & 0.39 \\
\hline Scheduled Damages [D] (+) & 0.20 & 0.40 & 0.26 & 0.44 & 0.22 & 0.42 \\
\hline Non-Econ Compensation (euros) $(+)$ & 232,437 & 216,425 & 156,632 & 205,847 & 209,561 & 215,521 \\
\hline Ln(Non-Econ Compensation) (+) & 11.8 & 1.23 & 11.41 & 0.99 & 11.69 & 1.18 \\
\hline Per-diem [D] (+) & 0.03 & 0.18 & 0.02 & 0.14 & 0.03 & 0.17 \\
\hline
\end{tabular}

Note: All financial variables are in 2010 real euros. [D] stands for dummy variables. (+) are variables available for cases in which compensation was granted. The total number of observations for cases with zero payout is 253 for Administrative; 113 for Civil; and 366 for all sample. The total number of observations for variables only available if compensation has been granted is 118 for Administrative; 55 for Civil; and 173 for all sample.

jor/grave injuries or death). The Civil Section analyzed a higher proportion of cases involving death while the Administrative Section decided a higher proportion of cases involving permanent major/grave injuries. ${ }^{31}$ In both Sections, the proportion of cases involving zero payouts was quite similar: 53\% for administrative decisions and 51\% for civil decisions. Approximately $60 \%$ of the claims involving a permanent major harm received compensation, followed by permanent minor cases with $45 \%$ and death cases with $37 \%$.

Figure 1 presents the distribution of non-economic damages. As it is usual in awards data,

\footnotetext{
${ }^{31}$ As will be explained in more detail in the empirical section, I performed Kolmogorov-Smirnov tests for the equality of distributions with respect to the levels of harm. No statistically significant differences on the distribution of cases decided by Administrative or Civil Sections were found.
} 
Table 2: SC decisions on Med Mal (Paid vs. Unpaid, by Level of Harm)

\begin{tabular}{llccccc}
\hline & & $\begin{array}{c}\text { Temporary } \\
\text { Emotional }\end{array}$ & $\begin{array}{c}\text { Permanent } \\
\text { Minor }\end{array}$ & $\begin{array}{c}\text { Permanent } \\
\text { Major/Grave }\end{array}$ & Death & Total \\
\hline \multirow{3}{*}{ Adm. } & Paid & 2 & 46 & 55 & 15 & $\mathbf{1 1 8}$ \\
& Unpaid & 11 & 56 & 39 & 29 & $\mathbf{1 3 5}$ \\
& Percentage Paid (\%) & 15.4 & 45.1 & 58.5 & 34.1 & $\mathbf{4 6 . 6}$ \\
\hline \multirow{3}{*}{ Civil } & Paid & 5 & 22 & 17 & 11 & $\mathbf{5 5}$ \\
& Unpaid & 7 & 26 & 9 & 15 & $\mathbf{5 7}$ \\
& Percentage Paid (\%) & 41.7 & 45.8 & 65.4 & 42.3 & $\mathbf{4 9 . 1}$ \\
\hline
\end{tabular}

NOTE: The total number of decisions at the Civil Section was 113. However in one case the patient did not provide information on the harm suffered. For that reason we only have 112 decisions when we consider decisions by level of harm.

we can see a substantial fraction of zero observations and a skewed positive outcome (commonly known as the "Zeroes Problem" and commonly found in award data).

Figure 1: Distribution of payouts

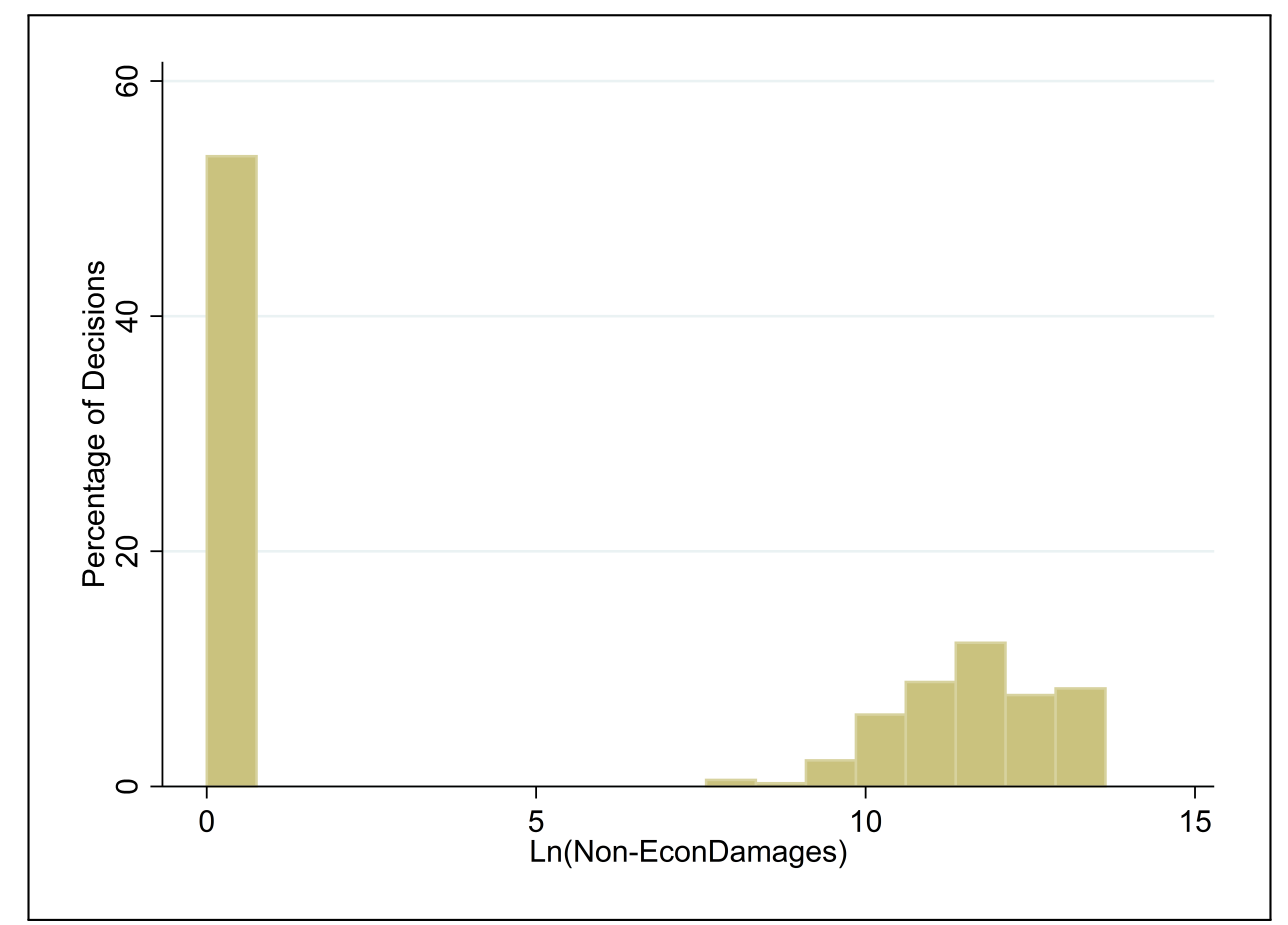

NOTE: Excludes two cases with payout higher than $€ 900,000$ (one from each Section, permanent grave injury cases).

Descriptive statistics for positive payout outcomes are provided in Table 3 . Claims involving the most severe levels of harm (permanent major injury, permanent grave injury, and death) account for $56 \%$ of the total number of paid claims but $84 \%$ of the total euro payout. At the Administrative Section these decisions account for $59 \%$ of paid claims and $85 \%$ of euro payouts while at the Civil Section these values were $53 \%$ and $82 \%$, respectively. Consistent with previous 
empirical results, I find that patients suffering permanent grave harm are those receiving the highest amount of compensation, even comparing to cases involving death.

Table 3: Summary Statistics for Non-Zero Payout Decisions (Non-economic damages, 2010€)

\begin{tabular}{llcccccc}
\hline \multirow{2}{*}{$\begin{array}{l}\text { Harm } \\
\text { Level }\end{array}$} & $\begin{array}{c}\text { N. of } \\
\text { Claims }\end{array}$ & $\begin{array}{c}\text { \% of } \\
\text { Total }\end{array}$ & $\begin{array}{c}\text { Total } \\
\text { Payout }\end{array}$ & $\begin{array}{c}\text { \% of } \\
\text { Total }\end{array}$ & $\begin{array}{c}\text { Mean } \\
\text { Payout }\end{array}$ & $\begin{array}{c}\text { Median } \\
\text { Payout }\end{array}$ \\
\hline \multirow{4}{*}{ Adm. } & Temp. Emot. & 2 & 1.7 & 40,120 & 0.15 & 20,060 & 20,060 \\
& Perm. Minor & 46 & 39 & $4,176,018$ & 15.2 & 90,783 & 58,950 \\
& Perm. Major & 22 & 18.6 & $4,960,693$ & 18.1 & 225,486 & 200,706 \\
& Perm. Grave & 33 & 28 & $15,456,607$ & 56.4 & 468,382 & 472,396 \\
& Death & 15 & 12.7 & $2,794,094$ & 10.1 & 186,273 & 166,024 \\
& All Levels & $\mathbf{1 1 8}$ & $\mathbf{1 0 0}$ & $\mathbf{2 7 , 4 2 7 , 5 3 2}$ & $\mathbf{1 0 0}$ & $\mathbf{2 3 2 , 0 5 4}$ & $\mathbf{1 6 9 , 9 3 2}$ \\
\hline \multirow{4}{*}{ Civil } & Temp. Emot. & 5 & 9.8 & 164,707 & 2.1 & 32,941 & 29,609 \\
& Perm. Minor & 19 & 37.2 & $1,239,869$ & 15.5 & 65,256 & 52,403 \\
& Perm. Major & 6 & 11.8 & $1,445,600$ & 18.1 & 240,933 & 233,639 \\
& Perm. Grave & 10 & 19.6 & $\mathbf{4 , 2 1 4 , 6 3 4}$ & 52.8 & 421,463 & 420,474 \\
& Death & 11 & 21.6 & 923,438 & 11.6 & 83,949 & 83,012 \\
& All Levels & $\mathbf{5 1}$ & $\mathbf{1 0 0}$ & $\mathbf{7 , 9 8 8 , 2 4 8}$ & $\mathbf{1 0 0}$ & $\mathbf{1 5 6 , 6 3 2}$ & $\mathbf{8 3 , 0 1 2}$ \\
\hline
\end{tabular}

Figure 2 displays the box plots for payouts according to the level of harm, at the Administrative and Civil Sections of the Spanish Supreme Court. We should not forget that this figure represents payouts by harm level only, but several other variables do play a role when awarding compensation. Nevertheless, some comparisons can be made although at this stage these are only crude comparisons. The line dissecting each box denotes the median payout for each level of harm. The median for cases involving death, permanent grave injuries and permanent minor injuries is higher at the Administrative Section. The median for permanent major injuries and temporary/emotional injuries is higher at the Civil Section. For both Sections, the highest dispersion is present for cases involving a permanent grave injury. Excluding cases of loss of a chance, awards could be as low as $€ 44,273$ and as high as $€ 1,080,000$ at the Administrative Section; and as low as $€ 56,892$ and as high as $€ 999,369$ at the Civil Section. The remaining injury levels have higher volatility if reaching Administrative courts ${ }^{32}$ Moreover, it seems that appealed cases involving death receive lower payouts in the civil jurisdiction: the median payout at the Administrative Section $(€ 176,850)$ is higher than the maximum at the Civil Section $(€ 141,170) 3$

\footnotetext{
${ }^{32}$ We are excluding loss of a chance cases. Temporary/emotional cases are excluded from these considerations as well, given that a very reduced number of cases of this type received a positive payout.

${ }^{33}$ See table in the Appendix for payouts according to the party appealing to the Supreme Court.
} 
Figure 2: Payouts per Harm Level

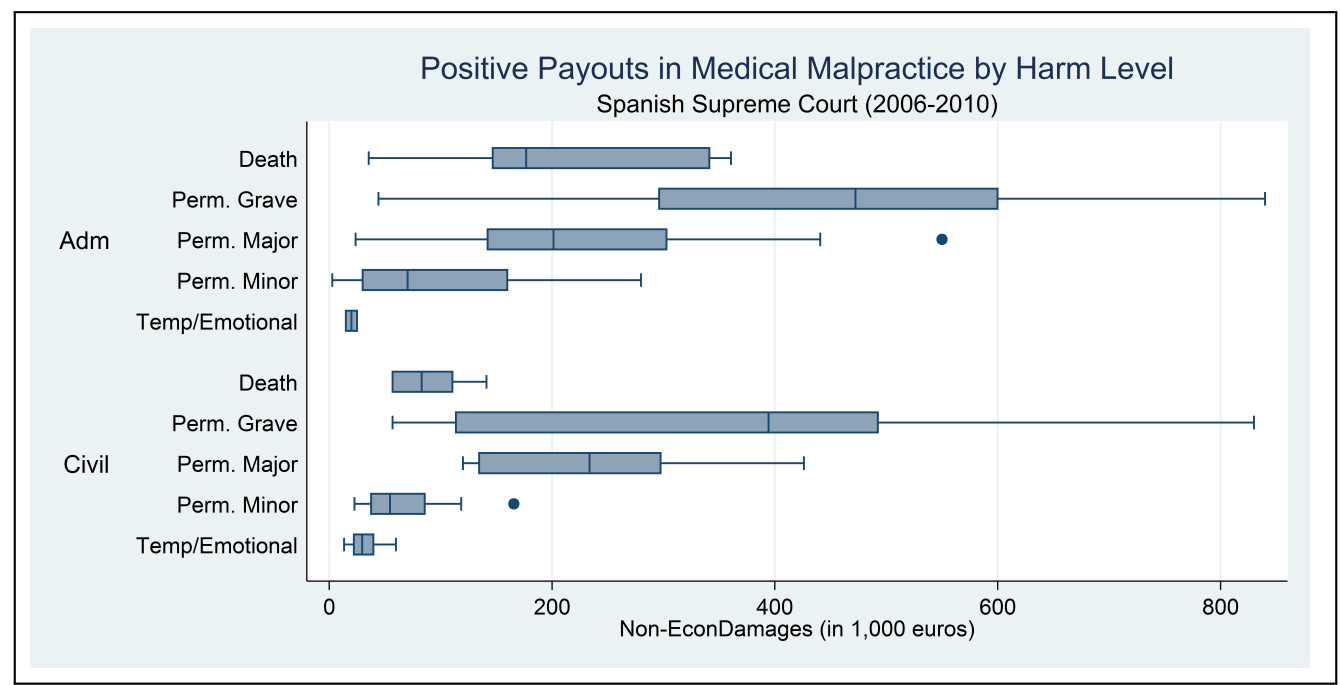

NotE: Excludes Loss of a Chance and two cases with payout higher than $€ 900,000$ (one from each Section, permanent grave injury cases).

\section{Empirical Strategy and Results}

The first part of the empirical analysis consists in assessing if there are any case characteristics that might have an impact on the probability of receiving compensation at the Spanish Supreme Court ${ }^{34}$ In the second part of the empirical analysis, I assess awards received by plaintiffs for non-economic damages. If non-economic damages are fairly set, there should be horizontal equity in payments with respect to the level of harm ${ }^{35}$ In other words, patients suffering similar injuries should receive comparable payouts (some case specific characteristics might have a role, which makes very unlikely to find exactly equal compensation amounts). Therefore, being a male $v s$. being a female, going to civil courts $v s$. going to administrative courts, coming from poorer regions $v s$. coming from richer regions should have no impact on compensation amounts. However, the tort system should provide vertical inequity: patients suffering higher levels of injury should receive higher non-economic damages than patients suffering lower injury levels.

One might worry that administrative cases can be different from civil cases in terms of characteristics that we cannot control for or that there might be a potential selection effect. The following has been made in order to overcome this possibility. First, I performed KolmogorovSmirnov tests for the equality of distribution of cases arriving to each section of the Supreme

\footnotetext{
${ }^{34}$ No claim will be made with respect to courts' ability of making correct or incorrect decisions, as it is impossible to have such a variable in our dataset. In Amaral-Garcia and Garoupa (forthcoming 2015) and Amaral-Garcia (2011) some reasons to rely on the Supreme Court decisions as the closest to a correct decision are given.

${ }^{35}$ The tort system can have many different objectives, and horizontal equity is not the only one. If it were, as Avraham (2006) argues, abolishing damages for pain and suffering would help achieving that goal.
} 
Court according to observable characteristics. No statistically significant differences were found. Second, if one believes that only the most difficult cases are appealed to the Supreme Court, then we should not see a high frequency of cases with the same outcome in each step of the litigation process (which account for more than half of the cases arriving at both sections of the Supreme Court). Third, appeals can be filed by the plaintiff or the defendant, and there is the presumption that state lawyers are expected to appeal up to the Supreme Court while out-of-court settlements are virtually not allowed ${ }^{36}$ Therefore, in case there was a selection effect according to which only the most difficult cases are appealed, we would expect it to be more likely in civil cases, as the State is essentially not involved in settlements. Were this to be true, we should not see more than half of the civil cases that reach the Supreme Court having always the same outcome. Forth, the aim of this part is precisely to assess outcomes of medical malpractice cases at the Supreme Court, and not to explain medical malpractice suits in general. Most importantly, even if one considers that a potential selection effect might exist, it is hard to imagine that it can have a role in setting non-economic damages when the most important characteristics are available for civil and administrative cases (namely the level of harm) and are controlled for in the regression analysis. Lastly, matching estimation and simulation are also performed ${ }^{37}$ By doing so, one can check whether there is evidence of significant different outcomes between matched cases, and between simulated and observed cases.

A two-part model was estimated, as reported in equations (1.a) and (1.b). The fist part (selection equation (1.a)) models the probability of receiving compensation as a binary outcome. The second part (outcome equation (1.b)) models the amount of non-economic compensation for those cases in which a payout has been awarded 38 Let NonEconCp denote non-economic compensation atributed at the Supreme Court, our dependent variable. Define the binary indicator $\mathrm{CP}$ such that $\mathrm{CP}=1$ if NONECONCP $>0$ (positive payout) and $\mathrm{CP}=0$ if $\mathrm{NONECONCP}=0$ (no payout). When NONECONCP $=0$, we can only observe $\operatorname{Pr}(\mathrm{CP}=0)$. For those cases with NONECONCP $>0$, let $\mathrm{f}(\mathrm{NONECONCP} \mid \mathrm{CP}=1)$ be the conditional density of NONECONCP. The outcome equation is a linear regression of the logarithm of NONECONCP on the set of explanatory variables, for those observations with CP equal to one. Several explanatory variables have been used, as described in Table 1. The Two-Part model for compensation can be written in the following way:

\footnotetext{
${ }^{36}$ Amaral-Garcia and Garoupa (forthcoming 2015).

${ }^{37}$ Please see subsection 4.2

${ }^{38}$ As widely recognized in the literature, this departure from the classical Tobit approach has the strength of allowing two different precesses: determining the decision of awarding compensation and determining its magnitude. Moreover, the Two-Part model is preferable to the Tobit since the homoskedasticity and normality hypotheses are not necessary conditions for consistency of the estimator (see for example Cameron and Trivedi (2005)).
} 
$f($ NonEconC $p \mid X)= \begin{cases}\operatorname{Pr}(\mathrm{CP}=0 \mid X) & \text { if NonEconC } p=0 \\ \operatorname{Pr}(\mathrm{CP}=1 \mid X) f(\text { NonEconC } p \mid \mathrm{CP}=1, X) & \text { if NonEconCp }>0\end{cases}$

\subsection{Results}

Table 4 shows the regression results for the two-part model for three different specifications. No strong differences seems to be apparent between civil and administrative cases, given that the dummy for administrative is generally not statistically significant (except in Model 1, for the selection equation). Appealing a decision in which the lower court delivered a pro-plaintiff outcome seems to increase the probability of receiving compensation, which is justified by the fact that the Supreme Court tends to agree with the lower court in the majority of cases.

Patients suffering permanent major/grave injuries have a higher probability of receiving compensation with respect to patients suffering temporary/emotional injuries (between 28\% to $29 \%$ higher). Cases involving injury to newborns are associated with a higher probability of receiving a positive payout (between $29 \%$ to $31 \%$ higher).

With respect to compensation levels, the results for the outcome equations show that cases involving permanent major injuries, permanent grave injuries and death receive much higher amounts of non-economic compensation in comparison with temporary/emotional injuries. Cases involving permanent grave injuries receive the highest non-economic damages, from $430 \%$ to $490 \%$ more than cases involving temporary/emotional injuries ${ }^{39}$ Permanent major injuries follow, receiving on average from $236 \%$ to $269 \%$ more than the baseline group. Cases involving death receive from $151 \%$ to $246 \%$ more than temporary/emotional cases. Finally, cases involving permanent minor injuries follow.

When courts consider that patients should be compensated under the loss of a chance doctrine, the levels of awards are considerably lower in comparison with cases being fully compensated. Using scheduled damages to quantify awards seems to have a statistically significant and positive impact on payouts.

Robustness checks based on these models have been performed, and the regressions results can be found in the Appendix. I considered identical econometric specifications with clustered standard errors at the regional level to control for intra-region correlations (Table A). With the aim of checking whether the decisions appealed to the Spanish Supreme Court show horizontal equity, a few regressions were run in the sub-sample of cases involving permanent minor injuries (Table B) and permanent major injuries (Table C) ${ }^{40}$ There is no evidence of significant

\footnotetext{
${ }^{39}$ I use $\exp (\beta-1) * 100 \%$ in order to obtain the exact percentage change.

${ }^{40}$ The sub-sample of cases involving death or temporary injuries was not considered, as the number of observations was quite small. I am aware that even for the sub-samples of permanent minor injuries and permanent major injuries
} 
Table 4: Regression Results

\begin{tabular}{|c|c|c|c|c|c|c|}
\hline \multirow[b]{2}{*}{ Dependent Variable } & \multicolumn{2}{|c|}{ Model 1} & \multicolumn{2}{|c|}{ Model 2} & \multicolumn{2}{|c|}{ Model 3} \\
\hline & СР & NonEconCp & $\mathrm{CP}$ & NonEconCp & $\mathrm{CP}$ & NonEconCp \\
\hline \multirow[t]{2}{*}{ Administrative } & $0.27^{* * *}$ & -0.21 & 0.11 & -0.30 & 0.08 & -0.18 \\
\hline & $(0.02)$ & $(0.45)$ & $(0.52)$ & $(0.49)$ & $(0.65)$ & $(0.69)$ \\
\hline \multirow[t]{2}{*}{ Lower Court Pro-Plaint } & $0.98 * * *$ & -0.14 & $0.98 * * *$ & -0.28 & $1.01 * * *$ & -0.30 \\
\hline & $(0.00)$ & $(0.43)$ & $(0.00)$ & $(0.14)$ & $(0.00)$ & $(0.12)$ \\
\hline \multirow[t]{2}{*}{ Male } & 0.02 & 0.06 & 0.02 & 0.04 & 0.04 & 0.20 \\
\hline & $(0.72)$ & $(0.69)$ & $(0.74)$ & $(0.78)$ & $(0.57)$ & $(0.19)$ \\
\hline \multirow[t]{2}{*}{ Permanent Minor } & 0.18 & $0.78 * *$ & 0.18 & $0.94 * * *$ & $0.21 *$ & $1.05 * * *$ \\
\hline & $(0.13)$ & $(0.01)$ & $(0.13)$ & $(0.01)$ & $(0.09)$ & $(0.00)$ \\
\hline \multirow[t]{2}{*}{ Permanent Major/Grave } & $0.28 * *$ & & $0.28 * *$ & & $0.29 * *$ & \\
\hline & $(0.04)$ & & $(0.04)$ & & $(0.03)$ & \\
\hline \multirow[t]{2}{*}{ Permanent Major } & & $1.86 * * *$ & & $1.88 * * *$ & & $1.99 * * *$ \\
\hline & & $(0.00)$ & & $(0.00)$ & & $(0.00)$ \\
\hline \multirow[t]{2}{*}{ Permanent Grave } & & $2.46 * * *$ & & $2.50 * * *$ & & $2.59 * * *$ \\
\hline & & $(0.00)$ & & $(0.00)$ & & $(0.00)$ \\
\hline \multirow[t]{2}{*}{ Death } & 0.19 & $1.41 * * *$ & 0.17 & $1.70 * * *$ & 0.16 & $1.90 * * *$ \\
\hline & $(0.18)$ & $(0.00)$ & $(0.23)$ & $(0.00)$ & $(0.29)$ & $(0.00)$ \\
\hline \multirow[t]{2}{*}{ Newborn } & $0.31 * *$ & 0.67 & $0.31 * *$ & 0.48 & $0.29 *$ & 0.06 \\
\hline & $(0.04)$ & $(0.12)$ & $(0.03)$ & $(0.26)$ & (0.09) & $(0.90)$ \\
\hline \multirow[t]{2}{*}{ Adult/Elderly } & 0.15 & 0.45 & 0.16 & 0.20 & 0.14 & 0.18 \\
\hline & $(0.18)$ & $(0.28)$ & $(0.18)$ & $(0.62)$ & $(0.24)$ & $(0.70)$ \\
\hline \multirow[t]{2}{*}{$\operatorname{Ln}(G D P p c)$} & -0.13 & -2.12 & 0.03 & 0.01 & 0.42 & 0.25 \\
\hline & $(0.91)$ & $(0.38)$ & $(0.98)$ & $(1.00)$ & $(0.72)$ & $(0.93)$ \\
\hline \multirow[t]{2}{*}{ Individual Defendant } & & & -0.16 & 0.06 & -0.18 & 0.17 \\
\hline & & & $(0.28)$ & $(0.85)$ & $(0.27)$ & $(0.64)$ \\
\hline \multirow[t]{2}{*}{ Pos 1998 Reform } & & & 0.05 & -0.18 & 0.06 & -0.18 \\
\hline & & & $(0.60)$ & $(0.33)$ & $(0.53)$ & $(0.33)$ \\
\hline \multirow[t]{2}{*}{ Duration (Months) } & & & -0.00 & -0.01 & -0.00 & -0.01 \\
\hline & & & $(0.84)$ & $(0.29)$ & $(0.90)$ & $(0.46)$ \\
\hline \multirow[t]{2}{*}{ Obstetrics/Gynecology } & & & & & 0.05 & $0.68 * * *$ \\
\hline & & & & & $(0.65)$ & $(0.01)$ \\
\hline \multirow[t]{2}{*}{ Neuro/Orthopedics } & & & & & 0.05 & 0.26 \\
\hline & & & & & $(0.60)$ & $(0.32)$ \\
\hline \multirow[t]{2}{*}{ Anesth/Reanimation } & & & & & -0.21 & 0.32 \\
\hline & & & & & $(0.28)$ & $(0.37)$ \\
\hline General Surgery & & & & & 0.15 & 0.22 \\
\hline & & & & & $(0.23)$ & $(0.46)$ \\
\hline Emergency Medicine & & & & & 0.13 & 0.14 \\
\hline & & & & & $(0.31)$ & $(0.66)$ \\
\hline Hosp. Beds $(1,000)$ & & & & & 0.45 & -2.42 \\
\hline & & & & & $(0.55)$ & $(0.25)$ \\
\hline Public Hosp. Beds $(1,000)$ & & & & & 0.35 & 2.88 \\
\hline & & & & & $(0.58)$ & $(0.20)$ \\
\hline LossOfChance & & & & $-0.75 * * *$ & & $-0.80 * * *$ \\
\hline & & & & $(0.01)$ & & $(0.00)$ \\
\hline Scheduled Damages & & & & $0.41 * *$ & & $0.45^{* *}$ \\
\hline & & & & $(0.03)$ & & $(0.02)$ \\
\hline Observations & 362 & 168 & 361 & 167 & 361 & 167 \\
\hline Adjusted R-squared & & 0.483 & & 0.517 & & 0.520 \\
\hline
\end{tabular}

Notes: Robust $p$-values in parentheses: $* * * \mathrm{p}<0.01, * * \mathrm{p}<0.05$, ${ }^{*} \mathrm{p}<0.1$. All regressions included a constant, dummies for the type of hospital, individual defendant, region fixed effects and year trend. The dependent variable $C P$ is one if the Supreme Court attributed compensation; and the dependent variable NonEconCp is the log of the non-economic compensation. Regressions with $C P$ as dependent variable present coefficients in marginal effects.

the number of observations is not very high. 
differences in compensation amounts between the Administrative and Civil Sections.

\subsection{Matching and Simulation}

The aim of this subsection is twofold. Firstly, I provide further robustness checks for the results presented in the previous subsection by estimating with a matching procedure the effect of administrative courts judging the case. Secondly, I present a simulation exercise to evaluate the counterfactual compensation under different scenarios.

I start by using propensity score matching in order to match administrative cases with civil cases. In this setting, "Administrative" is the treatment group and "Civil" the control group. As it is usual in matching estimation, the aim is to compare outcomes of the treated and control groups. Table 5 presents the average treatment effect on the treated (ATT), using kernel matching.

Table 5: ATT estimation with the Kernel Matching method

\begin{tabular}{|c|c|c|c|}
\hline & ATT & Std. Err. & $\mathrm{t}$ \\
\hline \multicolumn{4}{|c|}{ Probability of receiving compensation } \\
\hline Specification as in Reg 1 , Table 4 & 0.04 & 0.148 & 0.271 \\
\hline Specification as in Reg 3, Table 4 & 0.04 & 0.150 & 0.267 \\
\hline Specification as in Reg 5, Table 4 & 0.04 & 0.147 & 0.272 \\
\hline \multicolumn{4}{|l|}{ Amount of compensation } \\
\hline Specification as in Reg 2, Table 4 & 0.374 & 0.346 & 1.080 \\
\hline Specification as in Reg 4, Table 4 & 0.374 & 0.342 & 1.093 \\
\hline Specification as in Reg 6, Table 4 & 0.374 & 0.342 & 1.092 \\
\hline
\end{tabular}

No statistically significant differences were found between treatment and control groups with respect to the probability of receiving compensation and the amount of compensation. The results are in line with those previously presented.

Subsequently, I compute counterfactual outcomes. In this simulation exercise, I use the estimated model to predict the counterfactual outcome for an administrative case, would it have been decided by the Civil Section. Therefore, for each administrative case, I run 1,000 simulations in order to compute the simulated probability of receiving compensation and, in case compensation has been awarded, the respective simulated amount of damages. To obtain the average simulated compensation, I calculate the mean compensation for each administrative observation that received compensation, using the simulated outcomes per observation. Figure 3 shows the box plot for observed and simulated administrative outcomes to which compensation has been awarded. This figure points to less variation for simulated cases with respect to 
the observed ones (except for cases involving temporary/emotional injuries). Median simulated payouts are higher than observed payouts except for death cases.

Figure 3: Payouts for Adm. Observed and Simulated Outcomes

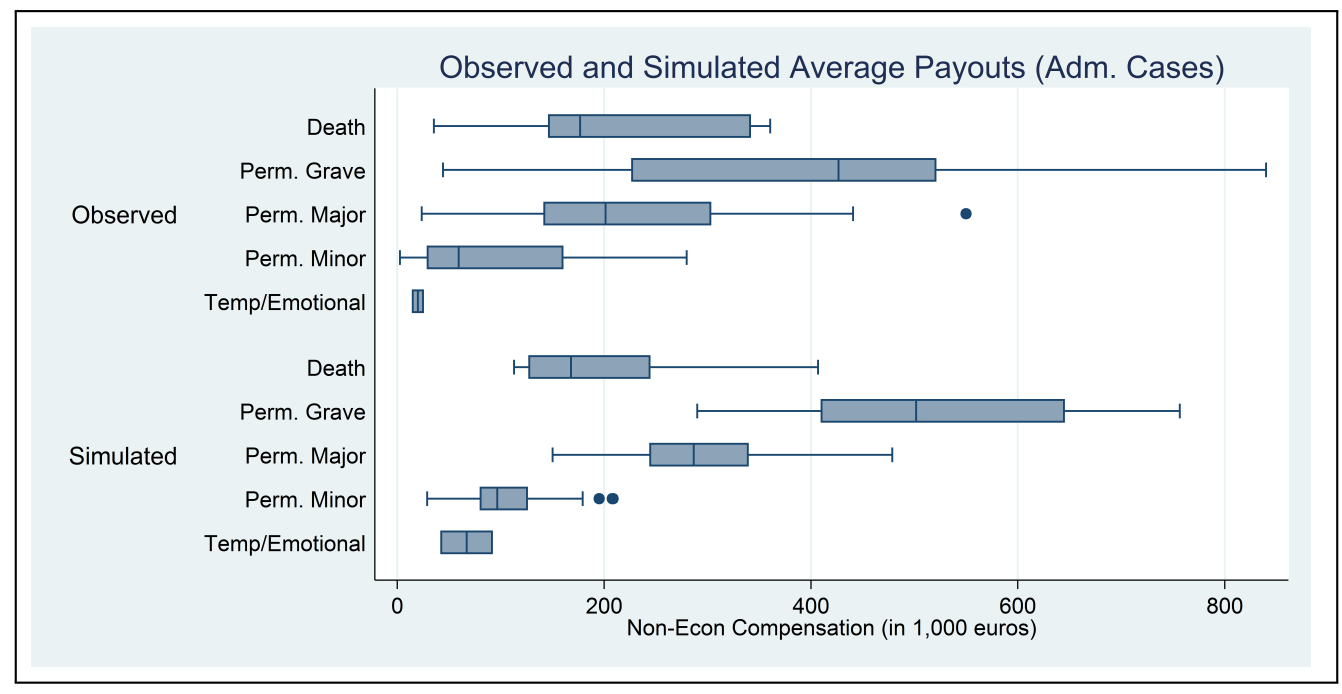

Note: Simulated outcomes obtained with 1,000 replications.

One important conclusion to take from this exercise is that there are no sizable differences between observed and simulated outcomes. In no case the range is completely outside the boundaries of the observed outcomes. In other words, the minimum for simulated outcomes is never higher than the maximum for observed cases; and the maximum for simulated cases is never lower than the minimum for observed cases (except for cases involving temporary/emotional injuries, which can be explained by the reduced number of observations).

As a final exercise, I compute the distribution of non-economic damages for simulated administrative cases and compare them with observed administrative outcomes. In Figure 4 it is possible to visualize the marginal distribution of both types of cases. There is essentially no difference in terms of the number of cases to which compensation has been refused $53.4 \%$ for observed cases and $54.4 \%$ for simulated cases). As for the distribution of cases receiving a positive payout, only small differences can be found 41 The frequency of cases attributing noneconomic damages from approximately 60,000 euros to 163,000 euros (group 5 in the graph) is higher for simulated cases than for observed cases (13\% vs. $8 \%$ of cases); and the same holds for cases receiving more than 420,000 euros (group 7 in the graph, $16 \%$ vs. $12 \%$ of cases).

\footnotetext{
${ }^{41}$ The $x$-axis corresponds to groups from 1 to 7 , in order to have both simulated and observed distributions in the same graph.
} 
Figure 4: Distribution of payouts: Observed and Simulated Administrative Decisions

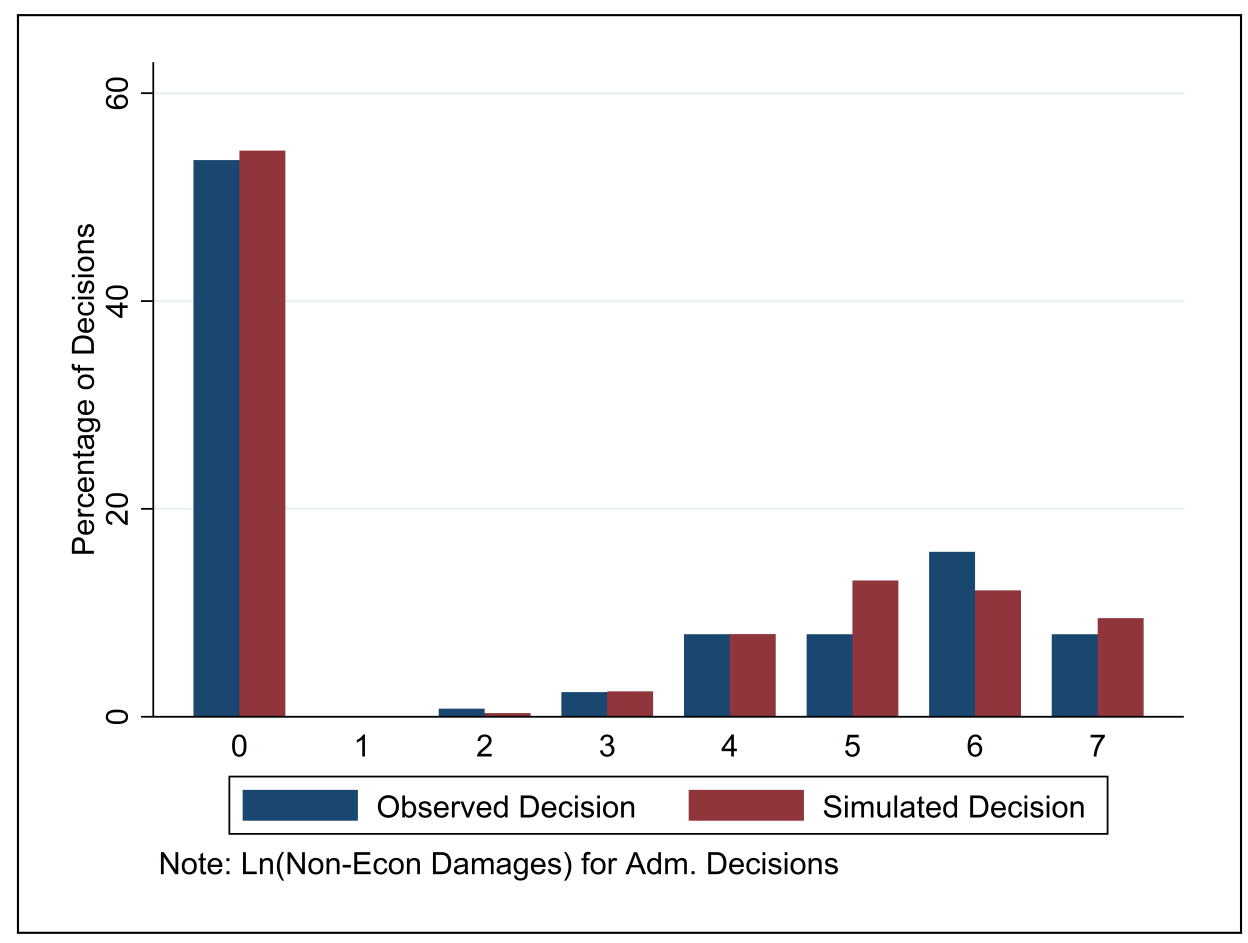

\section{Discussion}

\subsection{Predictors of Compensation}

The regression results show that suffering a permanent major/grave level of harm is a strong predictor of receiving compensation. Critics of the medical malpractice liability system argue that courts are awarding compensation to patients when there is no evidence of negligence and that this happens mainly in those cases involving a permanent disability. Recent empirical literature has shown that, even if the tort system is not perfect in matching merits of claims and outcomes, negligence matters to predict outcomes and the system is able to eliminate frivolous claims ${ }^{42}$ Although I found that higher levels of harm are strong predictors of receiving payouts, no claims should be made with respect to the correctness of the Spanish Supreme Court in judging medical malpractice cases. In fact, no variable that allows checking for negligence is available. However, it can be added that from those cases involving a permanent major/grave level of harm, the Spanish Supreme Court refused compensation in approximately one third

\footnotetext{
${ }^{42}$ For instance Rosenblatt and Hurst (1989), Cheney et al. (1989), Farber and White (1991), Sloan and Hsieh (1990), Taragin et al. (1992), Sloan et al. (1993), Farber and White (1994), Baker (2005b) and Studdert and Mello (2007).
} 
of cases: from 94 (26) cases arriving at the Administrative (Civil) Section, compensation was refused to 39 (9) cases. As for cases involving death, from 44 (26) Administrative (Civil) cases, compensation was denied in 29 (15) of them (Table 2). Therefore, suffering a high severity injury is not a sufficient condition to receive compensation: not every case involving permanent major/grave harm or death is compensated.

Cases in which the lower court delivered a pro-plaintiff outcome (i.e., defendant is guilty) are more likely to receive compensation at the Supreme Court. This result is in line with the fact that the majority of the appeals in civil law countries fail (Shavell (2010)). In other words, the Supreme Court can reverse outcomes from lower courts but it tends to confirm previous outcomes in the majority of cases (the overall agreement rate at the Supreme Court was $82 \%$ for medical malpractice cases). Therefore, the likelihood of having a pro-plaintiff outcome is higher if the lower court delivered a pro-plaintiff outcome as well, precisely due to the high agreement rate.

After controlling for several covariates I found that having a case being judged at the Administrative Section of the Supreme Court does not influence the probability of receiving compensation. This result is confirmed by further robustness checks (matching) and by simulation exercises.

\subsection{Amount of Non-economic Compensation}

No evidence of significant differences between non-economic compensation amounts attributed by the Administrative and Civil Sections was found. Therefore, generally speaking, one cannot claim that administrative and civil decisions appealed to the Supreme Court tend to exhibit different non-economic damages, controlling for case characteristics.

Also consistent with previous literature, the results show that patients suffering permanent major and permanent grave levels of harm are those receiving higher payouts, even comparing to cases involving death. Therefore, a vertical inequity in payments according to the level of harm is present in our data, but this is reasonable: patients suffering more serious injuries should be those receiving higher awards. Nevertheless, it is hard to make judgments in terms of horizontal equity of awards. Although Figure 2 seems to point to a high dispersion of payouts by harm level, regression results do not support it. Simulated results do not show striking difference with respect to observed outcomes. However, it is important to notice that observed cases have a higher dispersion, as Figure 3 shows.

Another relevant thing to assess is if the way that judges compute damages can influence how much plaintiffs receive. The results suggest that the use of scheduled damages is correlated with higher compensation amounts. After a closer look at the data it is possible to notice that, from the total of cases in which scheduled damages have been used, only one case had the 
computation of damages being made by the Supreme Court (all the remaining refer to cases in which lower courts attributed compensation, which means that the computation was made by these courts and not by the Supreme Court).

The fact that courts calculate damages in a non-systematic away might be problematic in the sense that patients cannot predict how much they can recover in terms of compensation, not even by looking at similar cases. This unpredictability might eventually result in a loss of deterrence if defendants believe that they might have to pay less for the harm they caused.

\section{Conclusions}

This article contributes to the empirical literature on non-economic damages in medical malpractice cases. It assesses predictors of compensation and amounts of non-economic compensation in Supreme Court decisions in Spain. It shows that, for Supreme Court decisions ruled upon from 2006 until 2010, there are no significant differences between administrative and civil cases in terms of predictors of compensation and non-economic damages. The results are confirmed by matching and simulation outcomes.

Patients suffering permanent grave and permanent major injuries are those receiving higher awards, even comparing to those cases involving death. Therefore, I found vertical inequality of awards by level of harm. However, it is harder to draw conclusions with respect to horizontal equity of payments. One important difference in terms of compensation has to do with the calculation approach chosen by the courts ${ }^{43}$ In fact, the use of scheduled damages is associated with higher non-economic compensation, which is evidence against equity in non-economic damages awards. Moreover, awards in which scheduled damages have been used refer essentially to decisions in which the lower court attributed compensation and the Supreme Court agreed with the decision, which means that the compensation amount was set by the lower court. The quantification of damages for physical injury and death is naturally a difficult task, but it has to be made. The lack of clear and consistent ways to quantify damages can make the problem more difficult for both judges and parties taking part in the litigation process.

Having different jurisdictions deciding similar types of cases is not a particularity of the Spanish legal system. Indeed, this is the general rule in civil law tradition countries. Differences in compensation awards from Civil and Administrative courts has been one argument widely used against the separation of jurisdictions. Although the aim of this paper is not to assess which system is better, it does show that this argument needs further empirical research.

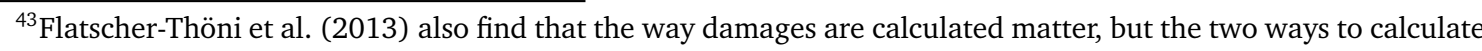
damages in their study are by use of a per-diem or a lump-sum.
} 


\section{References}

Abel, R. (2006). General Damages Are Incoherent, Incalculable, Incommensurable, and Inegalitarian (But Otherwise a Great Idea), DePaul Law Review 55 (2): 253-330.

Amaral-Garcia, S. (2011). Quantifying the Economics of Medical Malpractice - A View from a Civil Law Perspective.

Amaral-Garcia, S. (2015). Dano moral derivado de lesiones, in F. Gómez-Pomar and I. Marin Garcìa (eds), El Daño Moral y su quantificacion, Bosch.

Amaral-Garcia, S. (2015b). Encyclopedia of Law and Economics, Springer, chapter Administrative Courts.

Amaral-Garcia, S. and Garoupa, N. M. (forthcoming 2015). Do Administrative Courts Favor the Government? Evidence from Medical Malpractice in Spain, European Journal of Tort Law $73(3)$.

Arlen, J. (1985). An Economic Analysis of Tort Damages for Wrongful Death, New York University Law Review 60 (6): 1113-1136.

Arlen, J. (2000). Encyclopedia of Law and Economics, Edward Elgar, chapter Tort Damages, pp. 682-734.

Arroyo, M. C. and Yágüez, R. d. n. (2013). Medical Responsability and Liability in Spain, in S. D. Ferrara, R. Boscolo-Berto and G. Viel (eds), Malpractice and Medical Liability: European State of the Art and Guidelines, Springer.

Avraham, R. (2006). Putting a Price on Pain-and-Suffering Damages: A Critique of the Current Approaches and a Preliminary Proposal for Change, Northwestern University Law Review 100 (1): $87-120$.

Azagra-Malo, A. and Gili Saldaña, M. (2006). Ruleta Indemnizatoria y Tutela Judicial Efectiva, InDret .

Ben-Shahar, O. (2009). Tort Law and Economics, Encyclopedia of Law and Economics, Vol. 1, second edn, Edward Elgar, chapter Causation and Foreseeability, pp. 83-108.

Black, B., Hyman, D., Silver, C. and Sage, W. (2005). Stability, Not Crisis: Medical Malpractice Claim Outcomes in Texas, 1988-2002, Journal of Empirical Legal Studies 2(2): 207-259.

Bovbjerg, R. R., Sloan, F. A. and Blumstein, J. F. (1989). Valuing Life and Limb in Tort: Scheduling Pain and Suffering, Northwestern University Law Review 83 (4): 908. 
Buchanan, J. M. and Faith, R. L. (1979). Trying again to value a life, Journal of Public Economics 12(2): 245-248.

Cameron, A. C. and Trivedi, P. K. (2010). Microeconometrics Using Stata (Revised Edition), Stata Press.

Cameron, C, A. and Trivedi, P. K. (2005). Microeconometrics - Methods and Applications, Cambridge, University Press.

Chang, Y.-c., Eisenberg, T., Li, T. H. and Wells, M. T. (2013). An Empirical Study of Pain and Suffering Damages in Personal Injury Cases.

Coderch, P. S., Gonzalez, S. R., Yerga, A. L., Garcia, J. A. R., Alvarez, V. S., Saldana, A. G. and Crende, A. F. (2006). El Derecho Español de Daños en 2005, Global Jurist Topics 6(1): 1.

Cook, P. J. and Graham, D. A. (1977). The Demand for Insurance and Protection: The Case of Irreplaceable Commodities, The Quarterly Journal of Economics 91(1): 143-156.

Cooter, R. D. (1991). Economic Theories of Legal Liability, The Journal of Economic Perspectives 5(3): 11-30.

Cooter, R. and Porat, A. (2006). Liability Externalities and Mandatory Choices: Should Doctors Pay Less?, Journal of Tort Law 1 (1).

Danzon, P. M. (1985). Medical Malpractice: Theory, Evidence and Public Policy, Harvard University Press.

Dari-Mattiacci, G., Garoupa, N. M. and Gómez-Pomar, F. (2010). State Liability, European Review of Private Law 18 (4). Amsterdam Center for Law \& Economics Working Paper No. 2010-01; U. Illinois Law \& Economics Research Paper No. LE10-005.

Eisenberg, T. and Farber, H. S. (2003). The Government as Litigant: Further Tests of the Case Selection Model, American Law and Economics Review 5 (1): 94-133.

Eisenberg, T. and Heise, M. (2011). Judge-Jury Difference in Punitive Damage Awards: Who Listens to the Supreme Court?, Journal of Empirical Legal Studies 8 (2): 325-357.

Eisenberg, T., Wells, M. T. and Zhang, M. (2009). Regression Models for Trial Outcome Data with a Large Proportion of Zeroes, Presented at CELS .

Farber, H. S. and White, M. J. (1991). Medical Malpractice: An Empirical Examination of the Litigation Process, The RAND Journal of Economics 22(2): 199-217. 
Fenn, P., Diacon, S., Gray, A., Hodges, R. and Rickman, N. (2000). Current costs of medical negligence in NHS hospitals: analysis of claims database, BMJ 320: 1567-1571.

Ferrara, S. D., Boscolo-Berto, R. and Viel, G. (eds) (2013). Malpractice and Medical Liability: European State of the Art and Guidelines, Springer.

Flatscher-Thöni, M., Leiter, A. M. and Winner, H. (2013). Pricing Damages for Pain and Suffering in Court: The Impact of the Valuation Method, Journal of Empirical Legal Studies 10 (1): 104119.

Friedman, D. (1982). What is 'Fair Compensation» for Death or Injury?', International Review of Law and Economics 2: 81-93.

Garoupa, N., Gili, M. and Gómez-Pomar, F. (2012). Political Influence and Career Judges: An Empirical Analysis of Administrative Review by the Spanish Supreme Court, Journal of Empirical Legal Studies 9.4: 795-826.

Gómez-Pomar, F. (2001). Carga de la prueba y responsabilidad objetiva, InDret 01.

Gómez-Pomar, F. and Sánchez Álvarez, V. (2006). El Problema de la Responsabilidad de las Administraciones Públicas en Derecho Español: la visión del análisis económico de derecho, Sub Judice 34: 27-47.

Grembi, V. and Garoupa, N. M. (2013). Medical Malpractice in Civil Law: Some Evidence from the Italian Court of Cassation, Health Economics, Policy, and Law 8: 423-452.

Heckman, J. J. (1979). Sample Selection Bias as a Specification Error, Econometrica 47(1): 153161.

HMPS (1990). Harvard Medical Practice Study - Patients, Doctors and Lawyers: Medical Injury and Patient Compensation in New York - The Report of the Harvard Medical Practice Study on the State of New York.

Hyman, D. and Silver, C. (2006). Medical Malpractice Litigation and Tort Reform: Its the Incentives, Stupid, Vanderbilt Law Review 59(4): 1085-1136.

Karapanou, V. (2013). Pain and suffering damages based on QALYs: Circumventing victims' (and juries') hedonic misperceptions.

Karapanou, V. and Visscher, L. (2010). Towards a Better Assessment of Pain and Suffering Damages, Journal of European Tort Law 1(1): 48-74.

Koch, B. (ed.) (2011). Medical Liability in Europe - A Comparison of Selected Jurisdictions, Tort and Insurance Law (29), Walter De Gruyter. 
Leiter, A., Thöni, M. and Winner, H. (2012). Evaluating human life using court decisions on damages for pain and suffering, International Review of Law and Economics 32: 119-28.

Linnerooth, J. (1979). The Value of Human Life: A Review of the Models, Economic Inquiry 17(1): 52-74.

Luna Yerga, 1. (2005). Oportunidades Perdidas - La doctrina de la pérdida de oportunidad en la responsabilidad civil médico-sanitária, InDret 02.

Mahoney, P. (2001). The Common Law and Economic Growth: Hayek Might Be Right, Journal of Legal Studies 30: 503-25.

Martín-Casals, M., Ribot Igualada, J. and Solé Feliu, J. (2003). Medical Malpractice Liability in Spain: Cases, Trends and Developments, European Journal of Health Law 10(2): 153-81.

Mello, M. and Kachalia, A. (2010). Evaluation of Options for Medical Malpractice System Reform, MedPAC 10-2: 1-75.

Peeples, R., Harris, C. T. and Metzloff, T. B. (2002). The Process of Making Medical Malpractice Cases: The Role of Standard of Care, Wake Forest Law Review 37: 877-902.

Phillips, R. L. J., Bartholomew, L., Dovey, S., Fryer, G., Miyoshi, T. and Green, L. (2004). Learning from malpractice claims about negligent, adverse events in primary care in the United States, Quality \& Safety in Health Care 13(2): 121-126.

Pintos Áger, J. (2000). Scheduling Damage Awards, InDret 1.

Ramos González, S. and Luna Yerga, 1. (2004). Los baremos como paradigma de valoración de daños personales - Comentario a la STS, $1^{\text {a }}$, 20.6.2003, InDret 01.

Sage, W. M. (2003). Medical Liability and Patient Safety, Health Affairs 22 (4): 26-36.

Shavell, S. (2010). On the Design of the Appeals Process: The Optimal Use of Discretionary Review versus Direct Appeal, Journal of Legal Studies 39(1): 63-108.

Sloan, F. A. and Hsieh, C. (1990). Variability In Medical Malpractice Payments: Is The Compensation Fair?, Law \& Society Review 24: 997-1039.

Sloan, F., Mergenhagen, P. and Bovbjerg, R. (1989). Effects of Tort Reforms on the Value of Closed Medical Malpractice Claims: A Microanalysis, Journal of Health Politics, Policy and Law 663.

Spurr, S. J. and Howze, S. (2001). The effect of care quality on medical malpractice Litigation, The Quarterly Review of Economics and Finance 41: 491-513. 
Stremitzer, A. (2012). Negligence-Based Proportional Liability: How More Lenient Sanctions Lead to Higher Compliance, UCLA School of Law, Law-Econ Research Paper 12-10.

Studdert, D. M. and Mello, M. M. (2007). When Tort Resolutions are "Wrong": Predictors of Discordant Outcomes in Medical Malpractice Litigation, Journal of Legal Studies 36(S2): S47S78.

Studdert, D. M., Mello, M. M., Gawande, A. A., Gandhi, T. K., Kachalia, A., Yoon, C., Puopolo, A. L. and Brennan, T. A. (2006). Claims, Errors, and Compensation Payments in Medical Malpractice Litigation, New England Journal of Medicine 354 (19): 2024-2033.

Studdert, D. M., Thomas, E. J., Burstin, H. R., Zbar, B. I., Orav, E. J. and Brennan, T. A. (2000). Negligent Care and Malpractice Claiming Behavior in Utah and Colorado, Medical Care 38: 250.

Ubel, P. A. and Loewenstein, G. (2008). Pain and Suffering Awards: They Shouldn't Be (Just) about Pain and Suffering, Journal of Legal Studies 37: S195-S216.

Vidmar, N., Lee, P., MacKillop, K., McCarthy, K. and McGwin, G. (2005). Uncovering the "Invisible" Profile of Medical Malpractice Litigation: Insights from Florida, DePaul Law Review 54: 315-356.

Viscusi, K. (1988). Pain and suffering in product liability cases: Systematic compensation or capricious awards?, International Review of Law and Economics 8 (2): 203-220.

Viscusi, K. (1998). The New Palgrave Dictionary of Economics and the Law, Vol. 3, London, U.K.: Macmillan Publishers, chapter Valuing Life and Risks to Life, pp. 660-669.

Viscusi, K. (2004). Tort Reform and Insurance Markets, Risk Management and Insurance Review 7 (1): 9-24.

Visscher, L. (2009). Tort Law and Economics, Encyclopedia of Law and Economics, Vol. 1, second edn, Edward Elgar, chapter Tort Damages, pp. 153-200.

Zhou, J. (2010). Access to Justice: An Economic Approach, Dissertation Series, Center for Economic Research (Tilburg) 249. 


\section{Appendix}

Table 6: Injury Severity Levels

\begin{tabular}{ll}
\hline Severity of the injury & Description \\
\hline Emotional injury & Fright, no physical damage. \\
$\begin{array}{l}\text { Temporary insignificant } \\
\text { Temporary minor }\end{array}$ & Lacerations, contusions, minor scars, rash, no delay. \\
& $\begin{array}{l}\text { Fright, no physical damage; lacerations, contusions, minor scars, rash, no delay; } \\
\text { infections, mis-set fracture, fall in hospital - recovery delayed. }\end{array}$ \\
Temporary major & Burns,surgical material left, drug side effect - recovery delayed. \\
Permanent minor/significant $(*)$ & Loss of fingers, loss or damage to organs - includes nondisabling injuries; \\
& deafness, loss of limb, loss of eye, loss of one kidney or lung. \\
Permanent major/grave $(*)$ & Paraplegia, blindness, loss of two limbs, brain damage; quadraplegia, \\
& severe brain damage, lifelong care or fatal prognosis. \\
Permanent Major $(+)$ & Paraplegia, blindness, loss of two limbs, brain damage. \\
Permanent Grave $(+)$ & Quadriplegia, severe brain damage, lifelong care or fatal prognosis. \\
Death & \\
\hline
\end{tabular}

Notes: the source for this table is the NAIC.

(+) stands for variables available in case there is a positive payout only. (*) stands for my adaption of the original table.

Table 7: Non-Economic Damages by Injury Severity (Excludes Loss of a Chance)

\begin{tabular}{llcccccccccc}
\hline & \multicolumn{2}{c}{$<10,000 €$} & \multicolumn{2}{c}{$10,001-25,000 €$} & \multicolumn{2}{c}{$25,001-100,000 €$} & \multicolumn{2}{c}{$100,001-250,000 €$} & \multicolumn{2}{c}{$>250,001 €$} \\
\multicolumn{1}{c}{} & Harm & $N$ & Mean & $N$ & Mean & $N$ & Mean & $N$ & Mean & $N$ & Mean \\
\hline \hline \multirow{4}{*}{ Adm. } & Temp. Emot. & 0 & 0 & 1 & 15,000 & 1 & 25,120 & 0 & 0 & 0 & 0 \\
& Perm. Minor & 2 & 2,931 & 5 & 15,361 & 16 & 49,791 & 18 & 161,470 & 1 & 279,889 \\
& Perm. Major & 0 & 0 & 1 & 23,688 & 2 & 44,609 & 11 & 182,301 & 7 & 393,400 \\
& Perm. Grave & 0 & 0 & 0 & 0 & 1 & 44,273 & 5 & 170,473 & 26 & 548,611 \\
& Death & 0 & 0 & 0 & 0 & 2 & 46,133 & 5 & 163,919 & 4 & 324,723 \\
& All Levels & $\mathbf{2}$ & $\mathbf{2 , 9 3 1}$ & $\mathbf{7}$ & $\mathbf{1 6 , 4 9 9}$ & $\mathbf{2 2}$ & $\mathbf{4 7 , 6 1 5}$ & $\mathbf{3 9}$ & $\mathbf{1 6 8 , 8 1 4}$ & $\mathbf{3 8}$ & $\mathbf{4 8 9 , 3 8 0}$ \\
\hline \multirow{4}{*}{ Civil } & Temp. Emot. & 0 & 0 & 2 & 17,709 & 3 & 43,096 & 0 & 0 & 0 & 0 \\
& Perm. Minor & 0 & 0 & 1 & 22,757 & 12 & 53,743 & 3 & 130,765 & 0 & 0 \\
& Perm. Major & 0 & 0 & 0 & 0 & 0 & 0 & 4 & 180,489 & 2 & 361,821 \\
& Perm. Grave & 0 & 0 & 0 & 0 & 2 & 71,115 & 2 & 128,007 & 6 & 636,065 \\
& Death & 0 & 0 & 0 & 0 & 5 & 66,667 & 4 & 119,080 & 0 & 0 \\
& All Levels & $\mathbf{0}$ & $\mathbf{0}$ & $\mathbf{3}$ & $\mathbf{1 9 , 3 9 2}$ & $\mathbf{2 2}$ & $\mathbf{5 6 , 8 0 8}$ & $\mathbf{1 3}$ & $\mathbf{1 4 2 , 0 4 5}$ & $\mathbf{8}$ & $\mathbf{5 6 7 , 5 0 4}$ \\
\hline \hline
\end{tabular}


Table 8: Payouts by Appellant Party and Injury Severity (Excludes Loss of a Chance)

\begin{tabular}{|c|c|c|c|c|c|c|}
\hline & Harm & $N$ & Mean & Median & Minimum & Maximum \\
\hline \multirow{5}{*}{ Adm. Defendant Appeals } & Temp. Emot. & 0 & . & . & . & . \\
\hline & Perm. Minor & 7 & 139,435 & 160,000 & 54,000 & 210,232 \\
\hline & Perm. Major & 10 & 307,160 & 263,423 & 142,230 & 550,000 \\
\hline & Perm. Grave & 15 & 518,756 & 472,396 & 221,365 & $1,180,000$ \\
\hline & Death & 1 & 255,582 & 255,582 & 255,582 & 255,582 \\
\hline \multirow{5}{*}{ Adm. Plaintiff Appeals } & Temp. Emot. & 1 & 15,000 & 15,000 & 15,000 & 15,000 \\
\hline & Perm. Minor & 31 & 89,958 & 58,950 & 2,762 & 279,889 \\
\hline & Perm. Major & 11 & 163,674 & 166,024 & 23,688 & 340,776 \\
\hline & Perm. Grave & 15 & 405,654 & 450,000 & 44,273 & 650,668 \\
\hline & Death & 10 & 195,517 & 171,437 & 35,471 & 360,607 \\
\hline \multirow{5}{*}{ Both Adm. Parties Appeal } & Temp. Emot. & 1 & 25,120 & 25,120 & 25,120 & 25,120 \\
\hline & Perm. Minor & 4 & 75,233 & 56,506 & 11,068 & 176,850 \\
\hline & Perm. Major & . & . & . & . & . \\
\hline & Perm. Grave & 2 & 647,184 & 647,184 & 454,368 & 840,000 \\
\hline & Death & 0 & . & & . & . \\
\hline \multirow{5}{*}{ Civil Defendant Appeals } & Temp. Emot. & 3 & 30,523 & 29,609 & 22,136 & 39,824 \\
\hline & Perm. Minor & 12 & 68,738 & 54,647 & 22,757 & 165,810 \\
\hline & Perm. Major & 4 & 244,581 & 216,027 & 120,113 & 426,156 \\
\hline & Perm. Grave & 6 & 374,321 & 420,474 & 113,784 & 656,435 \\
\hline & Death & 4 & 103,628 & 96,847 & 79,649 & 141,170 \\
\hline \multirow{5}{*}{ Civil Plaintiff Appeals } & Temp. Emot. & 1 & 59,855 & 59,856 & 59,856 & 59,856 \\
\hline & Perm. Minor & 3 & 48,761 & 45,513 & 28,446 & 72,325 \\
\hline & Perm. Major & 1 & 235,113 & 235,113 & 235,113 & 235,113 \\
\hline & Perm. Grave & 2 & 71,115 & 71,115 & 56,892 & 85,338 \\
\hline & Death & 5 & 79,028 & 56,892 & 56,892 & 113,784 \\
\hline \multirow{5}{*}{ Both Civil Parties Appeal } & Temp. Emot. & 1 & 13,282 & 13,282 & 13,282 & 13,282 \\
\hline & Perm. Minor & 1 & 88,827 & 88,827 & 88,827 & 88,827 \\
\hline & Perm. Major & 1 & 232,165 & 232,165 & 232,165 & 232,165 \\
\hline & Perm. Grave & 2 & 913,238 & 913,238 & 830,107 & 996,369 \\
\hline & Death & 0 & . & . & . & . \\
\hline
\end{tabular}


Table A: Regression Results - clustered standard errors at the regional level

\begin{tabular}{|c|c|c|c|c|c|c|}
\hline \multirow[b]{2}{*}{ Dependent Variable } & \multicolumn{2}{|c|}{ Model 1} & \multicolumn{2}{|c|}{ Model 2} & \multicolumn{2}{|c|}{ Model 3} \\
\hline & $\mathrm{CP}$ & NonEconCp & $\mathrm{CP}$ & NonEconCp & $\mathrm{CP}$ & NonEconCp \\
\hline Administrative & $\begin{array}{l}0.22 * * \\
(0.01)\end{array}$ & $\begin{array}{c}-0.03 \\
(0.93)\end{array}$ & $\begin{array}{c}0.14 \\
(0.36)\end{array}$ & $\begin{array}{l}-0.12 \\
(0.70)\end{array}$ & $\begin{array}{c}0.10 \\
(0.56)\end{array}$ & $\begin{array}{c}0.00 \\
(0.99)\end{array}$ \\
\hline Lower Court Pro-Plaint & $\begin{array}{c}0.89 * * * \\
(0.00)\end{array}$ & $\begin{array}{c}-0.12 \\
(0.57)\end{array}$ & $\begin{array}{c}0.89 * * * \\
(0.00)\end{array}$ & $\begin{array}{c}-0.28 \\
(0.20)\end{array}$ & $\begin{array}{c}0.90 * * * * \\
(0.00)\end{array}$ & $\begin{array}{c}-0.31 \\
(0.21)\end{array}$ \\
\hline Male & $\begin{array}{c}0.03 \\
(0.56)\end{array}$ & $\begin{array}{c}0.04 \\
(0.74)\end{array}$ & $\begin{array}{c}0.03 \\
(0.56)\end{array}$ & $\begin{array}{c}0.04 \\
(0.71)\end{array}$ & $\begin{array}{c}0.03 \\
(0.66)\end{array}$ & $\begin{array}{c}0.18 \\
(0.12)\end{array}$ \\
\hline Permanent Minor & $\begin{array}{c}0.20 \\
(0.14)\end{array}$ & $\begin{array}{c}0.70 * * * * \\
(0.00)\end{array}$ & $\begin{array}{c}0.20 \\
(0.14)\end{array}$ & $\begin{array}{c}0.76 * * * * \\
(0.00)\end{array}$ & $\begin{array}{l}0.21 * \\
(0.10)\end{array}$ & $\begin{array}{c}0.84 * * * * \\
(0.00)\end{array}$ \\
\hline Permanent Major/Grave & $\begin{array}{l}0.29 * \\
(0.08)\end{array}$ & & $\begin{array}{l}0.29 * \\
(0.08)\end{array}$ & & $\begin{array}{l}0.32 * \\
(0.06)\end{array}$ & \\
\hline Permanent Major & & $\begin{array}{c}1.87 * * * \\
(0.00)\end{array}$ & & $\begin{array}{c}1.79 * * * \\
(0.00)\end{array}$ & & $\begin{array}{c}1.86 * * * \\
(0.00)\end{array}$ \\
\hline Permanent Grave & & $\begin{array}{c}2.44 * * * * \\
(0.00)\end{array}$ & & $\begin{array}{c}2.42 * * * \\
(0.00)\end{array}$ & & $\begin{array}{c}2.45^{* * * *} \\
(0.00)\end{array}$ \\
\hline Death & $\begin{array}{c}0.18 \\
(0.21)\end{array}$ & $\begin{array}{c}1.38 * * * * \\
(0.00)\end{array}$ & $\begin{array}{c}0.18 \\
(0.24)\end{array}$ & $\begin{array}{c}1.53 * * * \\
(0.00)\end{array}$ & $\begin{array}{c}0.20 \\
(0.32)\end{array}$ & $\begin{array}{c}1.70 * * * * \\
(0.00)\end{array}$ \\
\hline Newborn & $\begin{array}{c}0.28 * * * \\
(0.01)\end{array}$ & $\begin{array}{c}0.62 \\
(0.16)\end{array}$ & $\begin{array}{c}0.28 * * * \\
(0.01)\end{array}$ & $\begin{array}{c}0.47 \\
(0.32)\end{array}$ & $\begin{array}{l}0.23 * \\
(0.07)\end{array}$ & $\begin{array}{c}0.05 \\
(0.91)\end{array}$ \\
\hline Adult/Elderly & $\begin{array}{c}0.12 \\
(0.33)\end{array}$ & $\begin{array}{c}0.40 \\
(0.42)\end{array}$ & $\begin{array}{c}0.12 \\
(0.33)\end{array}$ & $\begin{array}{c}0.19 \\
(0.71)\end{array}$ & $\begin{array}{c}0.10 \\
(0.32)\end{array}$ & $\begin{array}{c}0.15 \\
(0.77)\end{array}$ \\
\hline $\operatorname{Ln}(g d p p c)$ & $\begin{array}{c}0.01 \\
(0.87)\end{array}$ & $\begin{array}{c}-0.21 \\
(0.41)\end{array}$ & $\begin{array}{c}0.01 \\
(0.87)\end{array}$ & $\begin{array}{l}-0.33 \\
(0.26)\end{array}$ & $\begin{array}{c}0.04 \\
(0.71)\end{array}$ & $\begin{array}{c}-0.34 \\
(0.21)\end{array}$ \\
\hline Individual Defendant & & & $\begin{array}{l}-0.07 \\
(0.63)\end{array}$ & $\begin{array}{l}-0.05 \\
(0.82)\end{array}$ & $\begin{array}{c}-0.10 \\
(0.53)\end{array}$ & $\begin{array}{c}0.03 \\
(0.91)\end{array}$ \\
\hline Pos 1998 Reform & & & $\begin{array}{c}-0.02 \\
(0.73)\end{array}$ & $\begin{array}{l}-0.09 \\
(0.47)\end{array}$ & $\begin{array}{c}-0.01 \\
(0.89)\end{array}$ & $\begin{array}{l}-0.08 \\
(0.54)\end{array}$ \\
\hline Duration (Months) & & & $\begin{array}{l}-0.00 \\
(0.79)\end{array}$ & $\begin{array}{l}-0.00 \\
(0.25)\end{array}$ & $\begin{array}{l}-0.00 \\
(0.76)\end{array}$ & $\begin{array}{l}-0.00 \\
(0.86)\end{array}$ \\
\hline Obstetrics/Gynecology & & & & & $\begin{array}{c}0.06 \\
(0.67)\end{array}$ & $\begin{array}{c}0.69 * * * * \\
(0.00)\end{array}$ \\
\hline Neuro/Orthopedics & & & & & $\begin{array}{c}0.02 \\
(0.80)\end{array}$ & $\begin{array}{c}0.25 \\
(0.18)\end{array}$ \\
\hline Anesth/Reanimation & & & & & $\begin{array}{c}-0.20 \\
(0.41)\end{array}$ & $\begin{array}{c}0.25 \\
(0.42)\end{array}$ \\
\hline General Surgery & & & & & $\begin{array}{c}0.06 \\
(0.71)\end{array}$ & $\begin{array}{c}0.14 \\
(0.45)\end{array}$ \\
\hline Emergency Medicine & & & & & $\begin{array}{c}0.04 \\
(0.77)\end{array}$ & $\begin{array}{c}0.11 \\
(0.61)\end{array}$ \\
\hline Hosp. Beds $(1,000)$ & & & & & $\begin{array}{c}-0.08 * * \\
(0.03)\end{array}$ & $\begin{array}{c}-0.01 \\
(0.91)\end{array}$ \\
\hline Public Hosp. Beds $(1,000)$ & & & & & $\begin{array}{c}-0.05 \\
(0.34)\end{array}$ & $\begin{array}{c}0.16 \\
(0.28)\end{array}$ \\
\hline LossOfChance & & & & $\begin{array}{c}-0.67 * * \\
(0.02)\end{array}$ & & $\begin{array}{c}-0.74 * * * \\
(0.01)\end{array}$ \\
\hline Scheduled Damages & & & & $\begin{array}{l}0.40^{*} \\
(0.09)\end{array}$ & & $\begin{array}{l}0.43 * * \\
(0.04)\end{array}$ \\
\hline Observations & 363 & 168 & 362 & 167 & 362 & 167 \\
\hline R-squared & & 0.530 & & 0.579 & & 0.601 \\
\hline
\end{tabular}

Notes: $p$-values in parentheses: $* * * \mathrm{p}<0.01,{ }^{* *} \mathrm{p}<0.05,{ }^{*} \mathrm{p}<0.1$. All regressions included a constant, dummies for the type of hospital and year trend. The dependent variable $C P$ is one if the Supreme Court attributed compensation; and the dependent variable NonEconCp is the log of the non-economic compensation. Regressions with $C P$ as dependent variable present coefficients in marginal effects. 
Table B: Regression Results - subsample of cases with Permanent Minor injuries

\begin{tabular}{|c|c|c|c|c|c|c|}
\hline \multirow[b]{2}{*}{ Dependent Variable } & \multicolumn{2}{|c|}{ Model 1} & \multicolumn{2}{|c|}{ Model 2} & \multicolumn{2}{|c|}{ Model 3} \\
\hline & $\mathrm{CP}$ & NonEconCp & СР & NonEconCp & $\mathrm{CP}$ & NonEconCp \\
\hline Administrative & $\begin{array}{c}0.48 * * * \\
(0.00)\end{array}$ & $\begin{array}{c}-0.40 \\
(0.37)\end{array}$ & $\begin{array}{l}0.46 * * \\
(0.04)\end{array}$ & $\begin{array}{c}-0.43 \\
(0.49)\end{array}$ & $\begin{array}{l}0.42 * \\
(0.08)\end{array}$ & $\begin{array}{l}-0.10 \\
(0.89)\end{array}$ \\
\hline \multirow[t]{2}{*}{ Lower Court Pro-Plaint } & $0.90 * * *$ & $-0.58 *$ & $0.90 * * *$ & $-0.65^{*}$ & $1.02 * * *$ & $-0.77^{*}$ \\
\hline & $(0.00)$ & $(0.05)$ & $(0.00)$ & $(0.07)$ & $(0.00)$ & $(0.06)$ \\
\hline \multirow[t]{2}{*}{ Male } & 0.10 & 0.06 & 0.10 & 0.10 & 0.04 & 0.28 \\
\hline & $(0.35)$ & $(0.82)$ & $(0.36)$ & $(0.72)$ & $(0.74)$ & $(0.34)$ \\
\hline \multirow[t]{2}{*}{ Newborn } & -0.10 & $2.12 * * *$ & -0.09 & $1.81 * *$ & -0.09 & 1.67 \\
\hline & $(0.72)$ & $(0.00)$ & $(0.74)$ & $(0.02)$ & $(0.79)$ & $(0.11)$ \\
\hline \multirow[t]{2}{*}{ Adult/Elderly } & 0.02 & $1.60 * * *$ & 0.01 & $1.40 * *$ & 0.11 & $1.39 *$ \\
\hline & $(0.92)$ & $(0.00)$ & $(0.95)$ & $(0.04)$ & $(0.60)$ & $(0.08)$ \\
\hline \multirow[t]{2}{*}{$\operatorname{Ln}(g d p p c)$} & $-0.57 * *$ & -0.35 & $-0.54 * *$ & -0.47 & $-0.91 * * *$ & -0.34 \\
\hline & $(0.02)$ & $(0.55)$ & $(0.03)$ & $(0.45)$ & $(0.01)$ & $(0.65)$ \\
\hline \multirow[t]{2}{*}{ Individual Defendant } & & & -0.01 & 0.05 & -0.09 & 0.39 \\
\hline & & & $(0.94)$ & $(0.91)$ & $(0.64)$ & $(0.33)$ \\
\hline \multirow[t]{2}{*}{ Pos 1998 Reform } & & & -0.11 & -0.22 & -0.05 & -0.30 \\
\hline & & & $(0.41)$ & $(0.55)$ & $(0.71)$ & $(0.39)$ \\
\hline \multirow[t]{2}{*}{ Duration (Months) } & & & -0.00 & -0.01 & -0.00 & 0.00 \\
\hline & & & $(0.91)$ & $(0.53)$ & $(0.64)$ & $(0.77)$ \\
\hline \multirow[t]{2}{*}{ Obstetrics/Gynecology } & & & & & -0.08 & $0.93 * *$ \\
\hline & & & & & $(0.67)$ & $(0.02)$ \\
\hline \multirow[t]{2}{*}{ Neuro/Orthopedics } & & & & & -0.05 & 0.23 \\
\hline & & & & & $(0.73)$ & $(0.53)$ \\
\hline \multirow[t]{2}{*}{ Anesth/Reanimation } & & & & & -0.49 & \\
\hline & & & & & $(0.12)$ & \\
\hline \multirow[t]{2}{*}{ General Surgery } & & & & & -0.23 & $0.80 *$ \\
\hline & & & & & $(0.21)$ & $(0.07)$ \\
\hline \multirow[t]{2}{*}{ Emergency Medicine } & & & & & -0.46 & 0.55 \\
\hline & & & & & $(0.10)$ & $(0.42)$ \\
\hline \multirow[t]{2}{*}{ Hosp. Beds $(1,000)$} & & & & & -0.06 & 0.37 \\
\hline & & & & & $(0.58)$ & $(0.14)$ \\
\hline \multirow[t]{2}{*}{ Public Hosp. $(1,000)$} & & & & & -0.28 & 0.10 \\
\hline & & & & & $(0.12)$ & $(0.79)$ \\
\hline \multirow[t]{2}{*}{ LossOfChance } & & & & -0.40 & & -0.44 \\
\hline & & & & $(0.30)$ & & $(0.33)$ \\
\hline \multirow[t]{2}{*}{ Scheduled Damages } & & & & 0.18 & & 0.12 \\
\hline & & & & $(0.61)$ & & $(0.72)$ \\
\hline Observations & 149 & 64 & 149 & 64 & 149 & 64 \\
\hline R-squared & & 0.227 & & 0.231 & & 0.378 \\
\hline
\end{tabular}

Notes: $p$-values in parentheses: $* * * \mathrm{p}<0.01, * * \mathrm{p}<0.05, * \mathrm{p}<0.1$. All regressions included a constant, dummies for the type of hospital and year trend. The dependent variable $C P$ is one if the Supreme Court attributed compensation; and the dependent variable NonEconCp is the log of the non-economic compensation. Regressions with $C P$ as dependent variable present coefficients in marginal effects. 
Table C: Regression Results - subsample of cases with Permanent Major injuries

\begin{tabular}{|c|c|c|c|c|c|c|}
\hline \multirow[b]{2}{*}{ Dependent Variable } & \multicolumn{2}{|c|}{ Model 1} & \multicolumn{2}{|c|}{ Model 2} & \multicolumn{2}{|c|}{ Model 3} \\
\hline & $\mathrm{CP}$ & NonEconCp & CP & NonEconCp & $\mathrm{CP}$ & NonEconCp \\
\hline Administrative & $\begin{array}{c}-0.08 \\
(0.63)\end{array}$ & $\begin{array}{c}0.33 \\
(0.42)\end{array}$ & $\begin{array}{c}0.04 \\
(0.88)\end{array}$ & $\begin{array}{c}-0.09 \\
(0.89)\end{array}$ & $\begin{array}{c}-0.08 \\
(0.76)\end{array}$ & $\begin{array}{c}-0.05 \\
(0.94)\end{array}$ \\
\hline \multirow[t]{2}{*}{ Lower Court Pro-Plaint } & $0.89 * * *$ & $0.31 *$ & $0.93 * * *$ & 0.09 & $1.13 * * *$ & 0.02 \\
\hline & $(0.00)$ & $(0.09)$ & $(0.00)$ & $(0.67)$ & $(0.00)$ & $(0.94)$ \\
\hline \multirow[t]{2}{*}{ Male } & -0.02 & 0.03 & -0.00 & 0.04 & 0.03 & 0.15 \\
\hline & $(0.85)$ & $(0.89)$ & $(0.97)$ & $(0.84)$ & $(0.81)$ & $(0.43)$ \\
\hline \multirow[t]{2}{*}{ Newborn } & $0.40 * *$ & 0.35 & $0.40 * *$ & 0.39 & 0.22 & 0.21 \\
\hline & $(0.03)$ & $(0.20)$ & $(0.02)$ & $(0.31)$ & $(0.44)$ & $(0.70)$ \\
\hline \multirow[t]{2}{*}{ Adult/Elderly } & 0.16 & -0.25 & 0.13 & -0.35 & 0.11 & -0.27 \\
\hline & $(0.40)$ & $(0.40)$ & $(0.46)$ & $(0.40)$ & $(0.57)$ & $(0.63)$ \\
\hline \multirow[t]{2}{*}{$\operatorname{Ln}(g d p p c)$} & $0.62 * *$ & -0.10 & $0.56 * *$ & -0.11 & $1.02 * * *$ & -0.71 \\
\hline & $(0.02)$ & $(0.85)$ & $(0.04)$ & $(0.81)$ & $(0.00)$ & $(0.21)$ \\
\hline \multirow[t]{2}{*}{ Individual Defendant } & & & 0.24 & -0.80 & 0.26 & -0.55 \\
\hline & & & $(0.23)$ & $(0.17)$ & $(0.15)$ & $(0.33)$ \\
\hline \multirow[t]{2}{*}{ Pos 1998 Reform } & & & 0.15 & 0.12 & $0.28 * *$ & 0.06 \\
\hline & & & $(0.30)$ & $(0.61)$ & $(0.04)$ & $(0.82)$ \\
\hline \multirow[t]{2}{*}{ Duration (Months) } & & & -0.00 & 0.00 & 0.00 & -0.01 \\
\hline & & & $(0.80)$ & $(0.97)$ & $(0.90)$ & $(0.59)$ \\
\hline \multirow[t]{2}{*}{ Obstetrics/Gynecology } & & & & & $0.69 * * *$ & $0.63 *$ \\
\hline & & & & & $(0.00)$ & $(0.09)$ \\
\hline \multirow[t]{2}{*}{ Neuro/Orthopedics } & & & & & $0.39 * *$ & 0.51 \\
\hline & & & & & $(0.02)$ & $(0.13)$ \\
\hline \multirow[t]{2}{*}{ Anesth/Reanimation } & & & & & 0.13 & $0.88 *$ \\
\hline & & & & & $(0.54)$ & $(0.10)$ \\
\hline \multirow[t]{2}{*}{ General Surgery } & & & & & $0.78 * * *$ & 0.56 \\
\hline & & & & & $(0.00)$ & $(0.32)$ \\
\hline \multirow[t]{2}{*}{ Emergency Medicine } & & & & & $0.74 * * *$ & -0.07 \\
\hline & & & & & $(0.00)$ & $(0.87)$ \\
\hline \multirow[t]{2}{*}{ Hosp. Beds $(1,000)$} & & & & & $-0.19 *$ & 0.19 \\
\hline & & & & & $(0.06)$ & $(0.29)$ \\
\hline \multirow[t]{2}{*}{ Public Hosp. Beds $(1,000)$} & & & & & 0.20 & -0.07 \\
\hline & & & & & $(0.11)$ & $(0.74)$ \\
\hline \multirow[t]{2}{*}{ LossOfChance } & & & & $-0.42 *$ & & -0.08 \\
\hline & & & & $(0.08)$ & & $(0.81)$ \\
\hline \multirow[t]{2}{*}{ Scheduled Damages } & & & & $0.59 * *$ & & $0.62 * *$ \\
\hline & & & & $(0.02)$ & & $(0.03)$ \\
\hline Observations & 120 & 71 & 120 & 71 & 120 & 71 \\
\hline R-squared & & 0.296 & & 0.421 & & 0.489 \\
\hline
\end{tabular}

Notes: $p$-values in parentheses: $* * * \mathrm{p}<0.01,{ }^{* *} \mathrm{p}<0.05, * \mathrm{p}<0.1$. All regressions included a constant, dummies for the type of hospital and year trend. The dependent variable $C P$ is one if the Supreme Court attributed compensation; and the dependent variable NonEconCp is the log of the non-economic compensation. Regressions with $C P$ as dependent variable present coefficients in marginal effects. 